
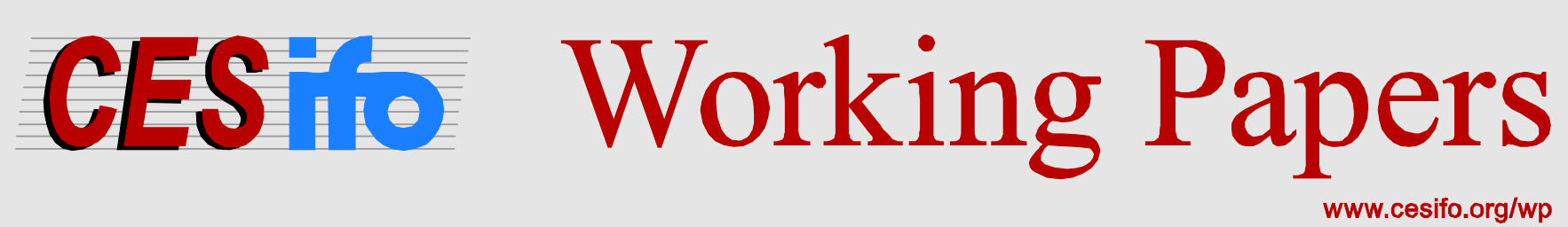

\title{
Shifting-Profits through Tax Loopholes. Evidence from Ecuador
}

\author{
Cyril Chalendard
}

CESIFO WORKING PAPER NO. 6240

CATEgORY 1: Public FinANCE

DECEMBER 2016

An electronic version of the paper may be downloaded

- from the SSRN website:

- from the RePEc website:

- from the CESifo website:

WwW.SSRN.com

Www.RePEc.org

www.CESifo-group.org/wp 


\title{
Shifting-Profits through Tax Loopholes. Evidence from Ecuador
}

\begin{abstract}
Based on a natural experiment that took place in Ecuador in the context of a capital outflow tax, this paper presents suggestive evidence of the emergence of an abnormal transfer pricing behavior. We exploit the fact that some imports were eligible to a tax-credit measure aiming to offset the capital outflow tax. The identification strategy relies on the fact that a foreign multinational enterprise has only an incentive to increase the unit value -transfer price- for profit shifting motivations of products eligible to the tax-credit. Then, comparing the evolution of the unit value of eligible products (the treatment group) with that of non eligible products (the comparison group) before and after the tax-credit measure, we estimate the over-reporting incentive's impact on the reported value. Results show that the declared unit value of eligible imports increased following the introduction of the tax-credit measure. Various tests suggest that this abnormal increase is attributable to a profit-shifting behavior.
\end{abstract}

JEL-Codes: F130, H250, H260, H320, K420.

Keywords: profit-shifting, tax evasion, transfer pricing, tax loophole, capital outflow tax, customs reform.

\author{
Cyril Chalendard \\ CERDI-University of Auvergne \\ Bd. F.Mitterrand, 65 \\ France - 63000 Clermont-Ferrand \\ cyril.chalendard@gmail.com
}

I would like to thank Simone Bertoli, Jean-Francois Brun, Thomas Cantens, Vianney Dequiedt, Sebastien Desbureaux, Hubert Kempf, Bertand Laporte, Luc Leruth, Gwenole Le Velly, Marcelo Olarreaga, Patrick Plane, Gregoire Rota-Graziosi, Georg Wamser and Martha Tesfaye Woldemichael for their useful comments/discussions (alphabetical order). I also wish to thank thank participants at the 9th Norwegian-German seminar on Public Economics, at the 65th Annual Meeting of the French Economic Association and at the CERDI internal Ph.D Seminar (October 2015). The responsibility for all interpretations and conclusions expressed in this article lies solely with the author. 


\section{Introduction}

Multinational enterprises (MNEs) tax contributions constitute an important component of total government revenues. According to UNCTAD (2015), foreign affiliates' contributions account for $10 \%$ of total revenues in developing countries. Despite such sizeable contributions, anecdotal evidence highlights that multinational enterprises dodge taxes through the use of aggressive tax planning strategies. Base Erosion and Profit shifting (BEPS) is thus an important issue for governments that want to secure revenues and restore tax fairness.

This paper contributes to the profit-shifting literature by providing suggestive evidence that MNEs may exploit tax loopholes to repatriate funds. Our study is based on a natural experiment that took place in Ecuador in the context of a capital outflow tax — named Impuesto a la Salida de Divisas, hereafter ISD tax- ${ }^{1}$. To promote local production, the Government of Ecuador (GoE) has offered tax-credits on the ISD paid for the importation of some inputs - mainly intermediate goods. MNEs have thus an incentive to manipulate transfer prices of (some) imports eligible to the tax-credit measure in order to escape the tax on capital outflows. In line with this expected response, we empirically find that following the introduction of the tax-credit measure, an abnormal increase of the unit value of products eligible to the tax-credit measure occurred.

We use a quasi-experimental framework — a difference-in-differences method - to estimate changes in transfer prices - i.e, changes in the declared import value - subsequent to the tax-credit measure. The identification strategy relies on the fact that MNEs do not have an incentive to modify their behaviors in setting transfer prices for products non eligible to the tax-credit measure. Due to data limitations, we do not know if the import operation is a related party transaction. In order to get a sample mainly formed by intra-group imports, we restrict our analysis to imports originating from countries whose exports to Ecuador are presumably, to a large extent, intra-group exports. Specifically, we retain only imports from top investor countries having signed a tax treaty with Ecuador. Results indicate that, after the introduction of the tax-credit measure, the manipulation of the import value increased the value of Ecuadorian imports by $26 \%$. As findings are highly dependent on the profit-shifting condition - i.e, a corporate income tax differential larger than taxes on imports-, the sudden increase seems not to be due to residents firms engaging in a capital flight behavior. The hypothesis that the increase in the declared unit value is attributable to a manipulation of transfer prices by MNEs is reinforced by the fact that the tax-credit measure has no impact on discrepancies in trade statistics - i.e., differences between recorded export values declared in the exporting country and import values declared in Ecuador-.

\footnotetext{
${ }^{1}$ As in many countries, profit shifting in Ecuador continues to pose important challenges. For instance, Ernst \& Young indicates, in its 2013 transfer pricing global reference guide, that litigations have increased in recent years in Ecuador, see the following web page: http://www.ey.com/GL/en/Services/ Tax/International-Tax/Transfer-Pricing-and-Tax-Effective-Supply-Chain-Management/ 2013-Transfer-pricing-global-reference-guide---Ecuador. Overall, bear in mind that, in developing/emerging countries, yearly tax losses due to transfer pricing manipulations and false invoicing are estimated at about $€ 100$ billion, see Eurodad (2013).
} 
From a public policy point of view, this article firstly highlights that tax expenditures should be carefully monitored. Basically, governments typically rely on tax-based incentives to reach some economic policy targets ${ }^{2}$. Granting tax deductions increases the expected profitability of targeted activities and thus aimed at stimulating such activities. However, tax-based incentives measures may also induce/create unintended negative responses - e.g. tax-credit frauds - which in turn may shape the policy's effectiveness ${ }^{3}$. Secondly, the study stresses that customs authorities should carefully monitor intra-group transactions. Customs should therefore play a substantial role in the fight against base erosion and profit shifting.

The remainder of the paper is structured in the following way. Section 2 briefly presents the extant literature on profit-shifting. Section 3 describes the Ecuadorian background. Section 4 presents the empirical strategy and the data. Results are presented in section 5 . Section 6 specifically discusses whether the increase in the declared unit value is attributable to profit-shifting or capital flight. Finally, section 7 concludes.

\section{Profit shifting literature}

Profit shifting is an activity whereby multinational corporations localise their profits in a specific country in order to reduce the overall tax burden. The "consensus estimate" suggests a tax semi-elasticity of pre-tax profits close to 0.8, see Heckemeyer and Overesch (2013). In other words, the Heckemeyer and Overesch (2013)'s prediction indicates that a one percentage point increase in the local's corporate tax reduces the affiliates' reported pre-tax profit by 0.8 percent $^{4}$. It is noteworthy that a smaller effect is found for studies based on firm-level microdata, see Dharmapala (2014). In order to minimize their overall tax liability, MNEs can shift profit through two main channels: the financing structure and transfer pricing in goods and services ${ }^{5}$.

Financial shifting techniques mainly consist in engaging in a debt-shifting behavior. The basic principle consists in assigning a large part of the MNEs' debt in high-tax jurisdictions

\footnotetext{
${ }^{2}$ For instance, a growing number of countries have set-up tax-credit schemes to stimulate private R\&D, for a review see e.g. Castellacci and Lie (2015).

${ }^{3}$ Anecdotal evidence also stresses that some firms typically abuse of these legal corporate tax loopholes. For instance abuse of the R\&D Irish tax-credit system has been recently stressed by the Irish Times, source: http://www.irishtimes.com/business/ revenue-to-move-on-tax-research-loophole-as-millions-lost-1.1491122. It is also worth mentioning that exemptions create opportunities for corruption, see Keen (2013).

${ }^{4}$ An impressive number of studies find evidence of profit shifting, see i.a Desai, Foley, and Hines (2006), Weichenrieder (2009). Profit shifting in developing countries is studied in Crivelli, De Mooij, and Keen (2015). For a survey of the empirical literature, see for instance the Dharmapala (2014)'s recent contribution. Increasing enforcement - through for instance the introduction of documentation rules - mitigates profit shifting, see e.g. Bartelsman and Beetsma (2003), Lohse, Hofmann, and Riedel (2015), Saunders-Scott (2013), Beer and Loeprick (2014).

${ }^{5}$ For a review of methods of corporate tax avoidance/evasion, see e.g. Gravelle (2009). Note that whereas tax avoidance is legal, tax evasion is illegal. The reader may refer to Devereux and Maffini (2007), De Mooij and Ederveen (2008) or Feld and Heckemeyer (2011) for a review of the not addressed issue between international capital flows and corporate income taxation.
} 
and a minor part in low-tax jurisdictions. The meta-study carried out by Feld, Heckemeyer, and Overesch (2013) stresses that taxes largely affect capital structure choices through the strategic use of the debt-to-asset ratio ${ }^{6}$. In particular, evidence of the use of intra-firm loans to shift profits has been found; see i.a., Desai, Foley, and Hines (2004), Egger, Eggert, Keuschnigg, and Winner (2010) or Buettner, Wamser, et al. (2013). Interestingly, the estimated effect is of quantitative importance. Riedel (2014) points that estimated semielasticities are generally close to unity i.e., a one percentage point increase in the corporate income tax rate implies a one percent increase of the affiliate's internal debt ratio. Finally, note that Fuest, Hebous, and Riedel (2011) argue that the use of intra-group borrowing for tax-reduction purposes seems to be much more prevalent in developing countries.

A second profit shifting channel consists in manipulating transfer prices. Transfer pricing refers to the pricing of goods, services or other assets in transactions between affiliated, see Lanz and Miroudot (2011). Basically, the purpose of this instrument is to optimally allocate expenses and revenues among affiliates within a group in order to minimize the worldwide tax liability. To this end, firms have an incentive to be vertically integrated, see Egger and Seidel (2013). Concerning intangibles, the literature stresses that intra-firm transfers related to the provision of services is a common practice to shift profits. By locating intangibles (brands, licenses, patents) in a low-tax jurisdiction and charging royalties for the use of intellectual property, then MNEs can shift profits from a high tax jurisdiction to a lowtax jurisidiction; for the U.S., see Grubert (2003), for the E.U., see i.a., Dischinger and Riedel (2011), Karkinsky and Riedel (2012). MNEs may also set tax-optimal transfer prices for intra-firm trade ${ }^{7}$ - i.e., under-valuing or over-valuing the transaction price - in order to maximize after-tax profits. Put differently, multinationals may voluntary set intra-firm prices different from arm's length prices - i.e, prices that would be settled on if the customer and the supplier were not related ${ }^{8}$. In practical terms, setting artificial transfer prices means that a high-tax affiliate overpays imports (resp. undervalue exports) from (resp. to) low-tax affiliates. Ernst \& Young, in a survey carried out in 2003, highlights that almost seven in ten international businesses respondents view transfer pricing as a way to "optimize tax arrangements"9. Evidence of the use of this tax-evasion technique has been inter alia found for U.S. (e.g., Grubert and Mutti (1991), Clausing (2003), Bernard, Jensen, and Schott (2006)), Danish (Cristea and Nguyen (2016)) or French (Davies, Martin, Parenti, and Toubal (2015), Vicard (2015)) MNEs.

\footnotetext{
${ }^{6}$ On this tax evasion method, see among others Huizinga, Laeven, and Nicodeme (2008) and Møen, Schindler, Schjelderup, and Tropina (2011).

${ }^{7}$ Following Lall (1973), we define in this study intra-firm trade as transactions involving international shipments of goods (excluding technology or services) between affiliates controlled by the same MNE group.

${ }^{8}$ Using the arm's length principle in order to correctly assess the value of intra-firm trade is questionable. For instance, Bauer and Langenmayr (2013) argue that multinationals are more productive than independent firms due to integration. It implies that a MNE may shift profits in setting a transfer price at the market value i.e., the comparable market price in accordance with the arm's length principle. As stressed by Keuschnigg and Devereux (2013), using the arm's length principle may also create distortions. In particular, they theoretically argue that, in order to overcome financing constraints, MNEs may shift profits for economic reasons. Alternative to the arm's length principle may be used to determine whether prices are set appropriately; for a discussion see for instance Hiemann and Reichelstein (2012).

${ }^{9}$ Source Hiemann and Reichelstein (2012).
} 


\section{Ecuadorian background}

\subsection{Tax reforms at a glance}

Ecuador is a middle income developing country. In January of 2000, the country adopted the U.S. dollar (hereafter USD) as its national currency to combat hyperinflation. It is worth mentioning that the economy is heavily dependent on non-renewable resource revenues. The oil production represents a large part of export revenues (50\%-60\%) and about $30 \%$ of government revenues ${ }^{10}$.

Since Rafael Correa first won power in end-2006, public spending - mainly public investment, public wages, subsidies and social spending ${ }^{11}$ — has risen sharply (see figure 1, left graph)). In order to balance the budget, the GoE has passed a series of tax reforms that increased the tax revenues to GDP ratio by more than a third during the first Correa administration - from 15 percent of GDP in 2006 to over 20 percent of GDP in 2013, see figure 1, right graph — ${ }^{12}$. Laws have, among others, increased (i) the personal income tax for high-income earners (creation of new ranges), (ii) the capital and property taxes, and (iii) the taxation of the financial sector. Other revenue raising measures included new taxes such as a tax on assets held abroad. In order to improve deterrence, anti-evasion laws have passed. These measures have notably made the firm's chief financial officer liable for tax-crimes and introduced imprisonment for evaders, see Aparicio, Carrillo, and Shahe Emran (2011).
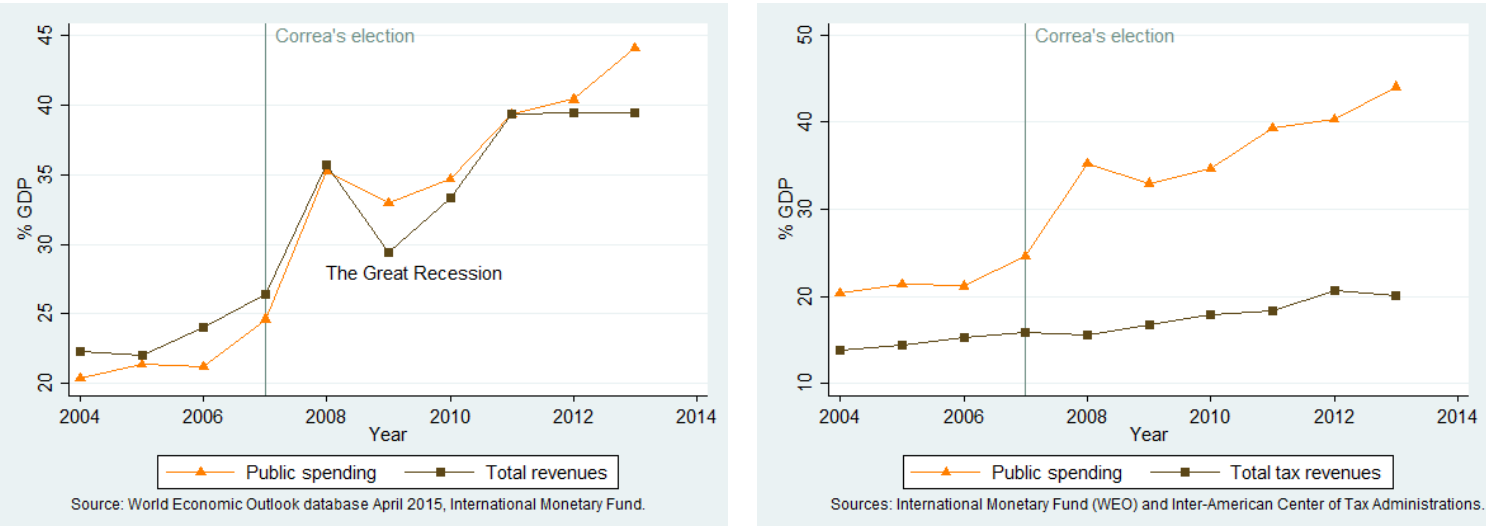

Figure 1: Evolution of main public finance indicators, period 2004-2013

Observation: The left figure plots public spending and revenues since 2004, on an annual frequency. The right figure shows public spending and tax revenues since 2004, on an annual frequency. In both graphs, the vertical line refers to the date at which Rafael Correa came to power. The difference between total revenues and total tax revenues is mainly imputable to oil revenues. Database sources: World Economic Outlook (International Monetary Fund) and Inter-American Center of Tax Administration.

\footnotetext{
${ }^{10}$ The gross domestic product per capita is USD $\$ 9,051$; the GDP per capita is based on purchasing power parity, year 2014, source: World Development Indicators (WDI). Note that, in addition to oil exports, remittances are also a sizeable source of revenues (2.6\% of GDP, year 2013, source: WDI).

${ }^{11}$ As for education spending, the reader may refer to Hidalgo, Onofa, Oosterbeek, and Ponce (2013).

${ }^{12}$ Notice that, since the voluntary default in 2008, Ecuador has suffered from a lack of access to international markets.
} 


\subsection{Corporate taxation (in 2013) ${ }^{13}$}

\subsubsection{The corporate income tax}

The corporate income tax (CIT) is levied on firms domiciled in Ecuador. Non-resident companies have to pay taxes on income derived from activities within Ecuador and from goods and assets located within Ecuador ${ }^{14}$. The standard rate of corporate income tax was $22 \%$ in $2013^{15}$. The tax burden is made-up of a $15 \%$ statutory profit-sharing distribution. The company's pre-income-tax profit represents a deductible expense for income tax purposes. Since we are interesting in studying tax optimization, we therefore consider this statutory contribution as an additional corporate income taxation. The profit-sharing distribution increases the corporate income taxation by $\left(15 \times \frac{100-22}{100}=\right) 11.7$ percentage points. The total corporate income tax burden is thus $33.7 \%(22 \%+11.7 \%)$.

\subsubsection{Transfer pricing rules}

Statutory rules. Transfer pricing rules have been introduced as part of the "income tax law" in January 2008. These rules regulate international trade transactions between related parties. Ecuador follows the Organization for Economic Cooperation and Development (OECD) guidelines ${ }^{16}$. Taxpayers must file with the internal revenue service a transfer pricing annex (resp. report) when their cross-border transactions with foreign-related parties exceed USD 3 (resp. 5) million. The burden of proof lies with the taxpayer ${ }^{17}$.

Arm's length price and transfer pricing methods. The arm's length principle is defined in Ecuador as "a situation wherein the terms and conditions agreed between related parties are similar to those agreed between third parties under similar circumstances", see Díaz Tong and Arenas Alvarado (2010). The arm's length price is determined following OECD transfer pricing methods. Ecuadorian regulations state that the comparable uncontrolled price method should be first used ${ }^{18}$.

\footnotetext{
${ }^{13}$ This section is based on various tax guides including the Deloitte Ecuador Highlights (2013), the HSBC Country Profile Ecuador (2013), the PKF Ecuador Tax Guide (2013), the PWC International transfer pricing guide (2013/14) and the PWC Worldwide Tax Summaries Corporate taxes (2013/14).

${ }^{14}$ Section 2 of the Internal Tax Regime Law outlines that the income tax shall be levied on "1. Income from an Ecuadorian source obtained by way of gift or for valuable consideration arising from work, capital, or both sources, in the form of money, in-kind items or services; and 2. Income obtained abroad by individuals residing in the country or by national companies", see Cevallos Pulley and Garca Balda (2013).

${ }^{15}$ Reinvested profits are taxed at $12 \%$.

${ }^{16}$ On May 2015, the tax authority introduced updated transfer pricing requirements for intercompany transactions, see Resolution No. NAC-DGERCGC15-00000455.

${ }^{17}$ Regarding thin capitalisation provisions, note that if the amount of a foreign loan exceeds three times the amount of the paid capital, the interest expense will not be considered as a deductible expense for incometax purposes. Furthermore, according to Deloitte, Ecuador has not introduced a controlled foreign company (CFC) regime, see https://www2.deloitte.com/content/dam/Deloitte/global/Documents/Tax/ dttl-tax-guide-to-cfc-regimes-210214.pdf.

${ }^{18}$ Other methods used are the resale price method, the cost plus method, the profit split method, the residual analysis profit split method and the transactional profit method.
} 


\subsubsection{Withholding taxes, double tax treaties and tax havens}

Withholding taxes. Dividend paid to non-resident entities (in non tax havens) are not subject to withholding taxes (WHTs). Other payments made abroad (including royalties, interest, technical services, technical assistance) are subject to a $22 \%$ WHT unless reduced by tax treaties, see table 1 .

Double tax treaties. Ecuador has a wide network of double tax treaties (see table 1). The country has notably entered into agreements to avoid international double taxation with Belgium, Brazil, Canada, Chile, France, Germany, Italy, Mexico, Romania, Spain, Switzerland and Uruguay. Relief from double taxation is also provided for natural and juridical persons located in any of the Andean Pact countries (see decisions 578 of the Cartagena Agreement).

Tax havens, low-tax jurisdictions and anti-tax haven measures. The list of tax havens is defined by the tax authority. A low-tax jurisdiction is defined in Ecuador as a jurisdiction with an effective rate of corporate income tax lower than $60 \%$ of the Ecuadorian applicable rate.

A lot of discriminatory measures against tax havens are currently in place ${ }^{19}$. Concerning income remittances, interest on loans and dividends remitted to a tax haven are subject to a withholding tax rate. Besides, the government recently increases the corporate income tax rate from $22 \%$ to $25 \%$ when the Ecuadorian firm's owners are residents of a tax-haven jurisdiction. Regarding resident firms, note that income obtained in a tax haven is treated as a residence-based income.

\subsubsection{The internal revenue service}

The Servicio de Rentas Internas - SRI - is an autonomous agency created in 1997. The SRI's efficiency has substantially increased in recent years. The cost of revenue collection -i.e. the ratio of current tax administration expenditures to tax revenue collection - has sharply declined (decrease of $28 \%$ between 2009 and 2013) ${ }^{20}$. Nevertheless, according to a recent Inter-American Development Bank report ${ }^{21}$, individual and business tax evasion remains non-negligible in Ecuador. One fifth (resp. one third) of (resp. VAT tax returns) business income tax returns are reported as non-compliant.

Regarding audits, controls are either extensive (automated checks) or intensive (field visits, intervention of an auditor). The SRI also conducts specific transfer pricing audits. Transfer pricing audits are often carried out in the export sectors of fruits, flowers, telecommunications and pharmaceuticals, see Díaz Tong and Arenas Alvarado (2010). Finally, note

\footnotetext{
${ }^{19}$ Notice that MNEs' investments in tax havens seem to be driven by tax planning motives. Gumpert, Hines Jr, and Schnitzer (2016) notably highlight that German multinational firms' investments in tax havens increase with the average tax rate at firms non-haven locations.

${ }^{20}$ In 2013 , the ratio of tax administration expenditures to tax revenue collection was USD $\$ 7.40$ per USD $\$ 1,000$ of tax revenue.

${ }^{21}$ See the IADB loan proposal (2014) "Internal Revenue Service Improvement Program".
} 
Table 1: Withholding taxes by country

\begin{tabular}{llllll}
\hline \multicolumn{1}{c}{ Country $\backslash$ WHT on } & Interest & Dividends & Royalties & Tech. services & Tech. assist \\
\hline Non treaty (and non tax havens) countries & $22 \%$ & $0 \%$ & $22 \%$ & $22 \%$ & $22 \%$ \\
Belgium & $10 \%$ & $0 \%$ & $10 \%$ & $0 \%$ & $0 \%$ \\
Bolivia & $0 \%$ & $0 \%$ & $0 \%$ & $0 \%$ & $0 \%$ \\
Brazil & $15 \%$ & $0 \%$ & $15 \%$ & $0 \%$ & $0 \%$ \\
Canada & $15 \%$ & $0 \%$ & $15 \%$ & $0 \%$ & $0 \%$ \\
Chile & $15 \%$ & $0 \%$ & $10-15 \%$ & $0 \%$ & $0 \%$ \\
Colombia & $0 \%$ & $0 \%$ & $0 \%$ & $0 \%$ & $0 \%$ \\
France & $10-15 \%$ & $0 \%$ & $15 \%$ & $0 \%$ & $0 \%$ \\
Germany & $10-15 \%$ & $0 \%$ & $15 \%$ & $0 \%$ & $0 \%$ \\
Italy & $10 \%$ & $0 \%$ & $5 \%$ & $0 \%$ & $0 \%$ \\
Mexico & $10-15 \%$ & $0 \%$ & $10 \%$ & $0 \%$ & $0 \%$ \\
Peru & $0 \%$ & $0 \%$ & $0 \%$ & $0 \%$ & $0 \%$ \\
Romania & $10 \%$ & $0 \%$ & $10 \%$ & $0 \%$ & $0 \%$ \\
Spain & $10 \%$ & $0 \%$ & $10 \%$ & $0 \%$ & $0 \%$ \\
Switzerland & $10 \%$ & $0 \%$ & $10 \%$ & $0 \%$ & $0 \%$ \\
Uruguay & $10 \%$ & $0 \%$ & $5-10 \%$ & $0 \%$ & $0 \%$ \\
Venezuela & $0 \%$ & $0 \%$ & $0 \%$ & $0 \%$ & $0 \%$ \\
\hline
\end{tabular}

Notes: Adapted from LATAXNET (2013).

Ecuador has a tax treaty with following countries: Belgium, Bolivia, Brazil, Canada, Chile, Colombia, France, Germany, Italy, Mexico, Peru, Romania, Spain, Switzerland, Uruguay, Venezuela.

that information sharing among revenue-collection authorities (customs and tax administration) is effective, see Carrillo, Shahe Emran, and Anita (2011) and Carrillo, Pomeranz, and Singhal (2016). Upon request, customs therefore provide information to the SRI.

\subsection{Taxation of cross border transactions}

\subsubsection{The capital outflow tax}

With the purpose of increasing revenues and stemming profit shifting/capital flight, the GoE set in 2008 a 0.5 percent tax on capital leaving the country - Impuesto a la Salida de Divisas (ISD) - . This tax (i) is charged on the value of all monetary foreign transactions, (ii) applies to all financial transfers in excess of USD $\$ 500^{22}$ and (iii) must be paid by all individuals and all - domestic and foreign - companies. Branches of foreign companies and permanent establishments domiciled in Ecuador are thus subject to this tax. For MNEs, this tax considerably increases the cost of repatriating funds to the headquarters. Even if the payment is made from abroad, the ISD tax must be paid (see Holguin (2011)) ${ }^{23}$.

The ISD tax has been raised incrementally to 5 percent in 2011. Banks have to collect the tax and then must refund revenues to the internal revenue service. In order to prevent

\footnotetext{
${ }^{22}$ To reduce evasion, since mid-August 2012 only two transfers per month have been tax-exempted.

${ }^{23}$ The payment is subject to the ISD tax even though it does not come from Ecuador.
} 
banks from netting their inflows and outflows, financial transfers have to channel through the Central Bank's accounts ${ }^{24}$. Increasing from USD \$31 million in 2008 to over USD \$1 billion in 2013 (see figure 2, left graph), the ISD is henceforth the third-largest source of tax income (after the value-added tax and the income tax).

To offset negative impacts on the local production, several tax-credit measures on imported goods were approved in (i) May 2012 (3,359 HS10-products), (ii) end-December 2012 (87 additional HS10-products), (iii) mid-January 2013 (250 additional HS10-products) ${ }^{25}$. The list has been revised in end-December $2013^{26}$. The tax reduction mechanism is straightforward: ISD paid on the import of eligible products is used as a tax-credit to offset income tax payments. Requesting this tax-credit from the tax authority is extremely simple. Companies have to enter the corresponding amount in a specific box (box 651) of the income tax return (F101 form, see Appendix B). This self-reported amount must be duly reasoned - supporting documents (bank statements, invoices) are required - and may be checked by the internal revenue service using customs data.

\subsubsection{Import taxes and other measures affecting imports}

The customs tariff is a major policy instrument in Ecuador. Therefore, although partly based on the Andean Community's common external tariff, the Ecuador's customs tariff remains relatively complex. The structure of tariff rates involves 17 ad valorem duties - specifically $0 \%$ and $5 \%$ for most raw materials and capital goods; $10 \%$ or $15 \%$ for intermediate goods; 20\%, 25\%, and 30\% for most consumer goods; and 35\% on motor carsand 10 compound duties ${ }^{27}$. Following the World Trade Organization (WTO) agreement on customs valuation, ad valorem duties are determined on the basis of the c.i.f. value ${ }^{28}$ (transaction value method). It is worth mentioning that Ecuador applies preferential rules of origin within the Andean Community and for some Mercosur - Mercado Comun del Surmember countries such as Argentina or Venezuela ${ }^{29}$.

In addition to customs tariffs, imports are subject to the value-added tax (VAT) the VAT standard rate is 12 percent of the c.i.f value ${ }^{30}$ - , a contribution to the children's development fund - the so-called Fodinfa, the standard rate is $0.5 \%$ of the c.i.f value-, customs charges and a special consumption tax — called ICE and applied to consumption of "sumptuous" goods such as alcoholic beverages, carbonated drinks, cigarettes-. Finally, some products - mainly agricultural and medical — are subject to an import licensing regime.

\footnotetext{
${ }^{24}$ See regulation 29 of the Central Bank, July 2012.

${ }^{25}$ See respectively internal revenue service resolutions CPT-03-2012, CPT-07-2012 and CPT-02-2013.

${ }^{26}$ See resolution CPT-04-2013.

${ }^{27}$ For more details, see trade policy reviews of the World Trade Organization.

${ }^{28}$ c.i.f. (cost, insurance and freight) means that the tax base equals the sum of the shipment's free-onboard value, the freight and the insurance.

${ }^{29}$ Ecuador is member of the Community of Andean Nations and an associate member of the Mercosur.

${ }^{30}$ Certain products (e.g. basic foods, pharmaceuticals, books and newspaper) are exempt or zero-rated.
} 


\subsubsection{The customs authority}

Previously perceived as largely corrupted and inefficient ${ }^{31}$, the customs authority - the National Customs Service of Ecuador (SENAE) - has undertaken an important modernization program in almost a decade. Efforts mainly sought to increase efficiency, promote ethical behaviors and facilitate trade. Pre-shipment inspections, previously mandatory for all shipments with a f.o.b (free-on-board) value greater than USD $\$ 4,000$, were replaced by a(n internal) risk analysis system run by customs. The customs authority has also redesigned/restructured its organizational structure and its processes to improve performances. Anti-corruption campaigns, spearheaded by a small group of reformers, resulted in the dismissal of about $5 \%$ of customs officers ${ }^{32}$. Procedures have been simplified through the implementation of a digital automated clearance system (ECUAPASS) ${ }^{33}$ and the establishment of a single window system. Together, these measures have facilitated trade - the frontline inspection rate has split by five (from $65 \%$ to $12 \%$ ) and the clearance time has more than halved (from 12 days to 5 days) - and have increased revenues (see figure 2, right graph).
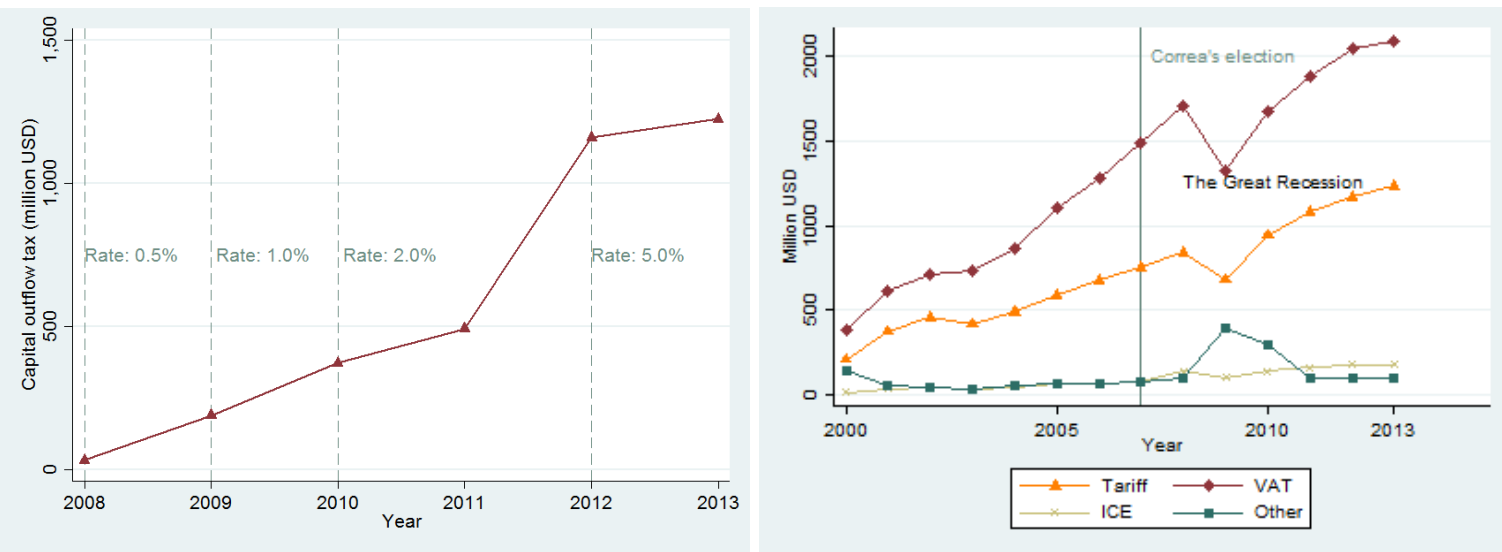

Figure 2: Evolution of customs revenues by tax

Observation: The left graph plots the evolution over the years of capital outflow tax revenues. The right graphs shows the evolution of major categories of customs revenues. Database source: Inter-American Center of Tax Administrations.

\section{Empirical strategy and data}

A non resident multinational enterprise has an incentive to shift profits from Ecuador to an another jurisdiction if the corporate tax burden (the corporate income tax rate) is re-

\footnotetext{
${ }^{31}$ For illustrative purposes, see the following article "Ecuador's customs: A tariff here, a bribe there" published by The Economist on June $28^{\text {th }} 2003$. With the purpose of tackling the collusion problem, military forces administered the customs administration from 2003 to 2005.

${ }^{32}$ The anti-corruption program is summarized in the June 2015 World Customs Organization integrity newsletter, available at the following address: www.wcoomd.org/en/media/newsroom/2015/june/ /media/ WCO/Public/Global/PDF/Topics/Integrity/Resources/Newsletters/WCOIntegrityNewsletter_ 11-EN.ashx.

${ }^{33}$ The cent per cent percent electronic SENAE's customs management information system (ECUAPASS) is based on the Korean system UNI-PASS. It cost more than USD $\$ 21$ million.
} 
duced in the latter. In our case, it means that MNEs want to shift profits if the tax burden is below 33.7\%. Overpricing imports from the parent company —i.e., setting an artificial high transfer price for intra-group imports - is interesting if and only if the corporate income tax differential - henceforth $\Delta$ CIT - is larger than (Ecuadorian) taxes on imports - excluding VAT (and the capital outflow tax), henceforth $\psi$. Since information sharing among revenuecollection authorities is effective, posing that affiliates declare a customs value equals to the transfer price is a reasonable assumption.

The introduction of a tax-credit offsetting the capital outflow tax on some imports in end-December 2012/mid-January 2013 has reduced the tax burden on these imports. This measure has therefore increased benefits for MNEs to shift profits through an overvaluation of intra-group imports. An increase in the declared internal transfer price -i.e., the declared import value - may thus be expected following the introduction of the tax-credit. Apart from this measure, there was no major corporate tax reforms in 2013 in Ecuador. Between 2012 and 2013, MNEs had thus no incentive to change their internal transfer prices of goods, except for economic reasons (inflation, exchange rate fluctuations ....). It implies that a multinational affiliate had no incentive to modify the declared import value for non economic - e.g. profit shifting - reasons between 2012 and 2013. Therefore, we do not expect a change in the manipulation of transfer prices for products not newly eligible to the tax credit measure during the year 2013. Put it differently, only an abnormal increase in the declared import value is expected for products newly eligible to the tax-credit measure (for profit shifting reasons).

Before empirically testing this assumption, we will describe in the remainder of this section our approach to identify the causal effect of the over-reporting incentive on the declared value for customs - i.e., the internal transfer price-. We will first describe the identification strategy, then we will present the data and the econometric specification. Finally, we will discuss possible identification threats.

\subsection{Identification strategy and outcome of interest}

Our identification strategy exploits the fact that MNEs do not have an incentive to modify their behaviors in setting transfer prices for products non eligible to the tax-credit measure. Based on this, we appeal to a difference-in-differences approach ${ }^{34}$. A comparison of the evolution of the declared unit value of eligible products with that of non eligible products before and after the tax-credit measure aims to provide an estimate of the over-valuing incentive's impact on the reported value. "Eligible products" are products eligible to the tax-credit measure. The treatment group is obviously formed by imports for which MNEs have an incentive to increase the declared value following the introduction of the tax credit measure - i.e., eligible goods (i) coming from a low-corporate income tax country ${ }^{35}$ and (ii)

\footnotetext{
${ }^{34}$ There is now a growing literature in public finance that applies this quasi-experimental method, for a brief review see Pomeranz (2015).

${ }^{35}$ We define a low-corporate income tax country as a country with a corporate income tax rate smaller than the Ecuadorian corporate tax burden rate $(33.7 \%)$.
} 
subject to an import taxation rate $\psi$ lower than the corporate income tax rate differential $\triangle C I T$. In order to get a control group with similar transfer pricing characteristics, we restrict the comparison group to products for which MNEs have an incentive to manipulate transfer prices -i.e., non eligible products (i) coming from a low-corporate income tax country and (ii) subject to an import taxation rate $\psi$ lower than the corporate income tax rate differential $\triangle C I T$ - . Notice that the increase in the declared unit value is only expected for eligible imports coming from a "relatively" low-tax country as the tax-credit measure does not applies to imports from tax havens and very low-tax jurisdictions -i.e., jurisdictions with a corporate income tax (CIT) rate below $60 \%$ the Ecuadorian CIT rate- We therefore exclude from the sample imports from tax-havens and very low-tax jurisdictions.

Although a non-negligible part of products eligible to the tax-credit measure are probably subject to intra-firm trade ${ }^{36}$, we are not able to precisely distinguish between intra-firm trade and inter-firm trade. Unfortunately, we have no information on the relationship between the importer and the exporter. By restricting our analysis to imports originating from non-tax haven countries (i) belonging to the 20 top investor countries in Ecuador and (ii) having signed a tax treaty (with Ecuador), we attempt to get a sample mainly formed by intra-group imports. As argued below, imports from these countries are probably, to a large share, intra-firm transactions.

Due to reduced payments for cross-border services (royalties, payments for services ...) and interest, repatriation of funds is, as highlighted in table 1, particularly attractive for investors from countries with a double taxation agreement (DTA) with Ecuador. These treaties create powerful incentives for multinational corporations based in countries having signed a DTA to establish subsidiaries in Ecuador. As a consequence, imports from these countries are probably to a non-negligible extent intra-group imports. Interestingly, with the introduction of the ISD tax, costs of repatriating funds have sharply increased for these MNEs. Thus, they have a strong incentive to request the Ecuadorian subsidiary to overvalue intra-group imports eligible to the tax-credit measure in order to shift Ecuadorian profits free of the capital outflow tax. Since we wish to get a sample only formed by intragroup imports, we choose to restrict our sample to imports from top source countries of foreign direct investment (into Ecuador). Table 2 presents, for each non tax-haven country having signed a tax treaty and belonging to the 20 top investor countries, payments sent under DTAs. Given that payments are sizeable - larger than USD $\$ 800$ million over the 2009-2011 period - , it suggests that a large number of affiliates have been created and currently operate in Ecuador. These flows account for $16 \%$ of total FDI net inflows over the period 1992-2012. Ecuadorian activities are therefore profitable. Such large payments in fine suggest highly frequent transactions between the Ecuadorian affiliates and parent companies.

As the tax-credit makes eligible products cheaper, the measure may affect true import quantities (due to a possible shift from non-eligible products to eligible products). This issue is addressed by considering the unit value rather than the total import value as our outcome measure.

\footnotetext{
${ }^{36}$ Indeed, a large part of eligible products are intermediate goods.
} 
Table 2: FDI and payments sent under DTAs, by country

\begin{tabular}{lll}
\hline Country & Total FDI & Payments sent under DTAs \\
\hline Years & $1992-2012$ & $2009-2011$ \\
\hline Canada & 1,724 & 159 \\
Chile & 318 & 105 \\
Colombia & 195 & 50 \\
Germany & 174 & 129 \\
Italy & 425 & 23 \\
Mexico & 1,417 & 123 \\
Peru & 88 & 26 \\
Spain & 695 & 188 \\
\hline
\end{tabular}

Database sources: Investment Map database and Cevallos Pulley and Garca Balda (2013).

Notes:

(i) All amounts are expressed in USD million.

(ii) Total FDI are cumulative FDI net inflows.

(iii) Statistics are only presented for non tax-haven countries (a) belonging to the 20 top investor countries in Ecuador, (b) having signed a tax treaty with Ecuador and (c) exporting eligible products to Ecuador.

Table 3 summarizes the identification strategy. Differences and similarities between treatment and control groups are notably stressed.

\subsection{Data and data restrictions}

Data. Ecuador customs have provided transaction-level import data. For each customs declaration, the database offers various information such as the HS-10 digit product code, the exporting country, the potential transit country, the mode of transport, the date of registration, the declared value, the declared quantity, the declared weight ... Tax-credit lists come from the Ecuadorian Tax Policy Committee's resolutions - El Comité de Politica Tributaria's resolutions - , downloaded from the Official Journal of the Republic of Ecuador - Registro Oficial - . Corporate income tax rates are downloaded from the Deloitte international tax source website (https://dits.deloitte.com/).

Data restrictions. Following the identification strategy described above, the treatment group is formed by products eligible to the tax-credit. The group is restricted to HS-10 products newly exempted from the ISD (i) at the end of 2012 (December $26^{\text {th }}$, second wave) or (ii) at the beginning of the year 2013 (January $21^{\text {th }}$, third wave) ${ }^{37}$. Then, in order to

\footnotetext{
${ }^{37}$ We restrict the treatment group to new HS10-products listed in resolutions CPT-07-2012 and CPT-022013. The exclusion of HS10-products mentioned in the first list (resolution CPT-03-2012, Apr 23 $3^{\text {th }}$ 2012) is motivated by the fact that the measure entered into force in the middle of the year. Besides, since the tax-credit list has been significantly revised in end-2013 (see the resolution CPT-04-2013, December $23^{\text {th }}$ ), we restrict our study period to the period 2012-2013.
} 
Table 3: Definition of treatment and control groups

\begin{tabular}{llcc}
\hline Incentive to & Condition & Treatment group & Comparison group \\
\hline Shift profits & $\Delta$ CIT $_{E c e}>0$ & $\checkmark$ & $\checkmark$ \\
Manipulate transfer prices & $\psi_{p e}<\Delta$ CIT $_{E c e}$ & $\checkmark$ & $\checkmark$ \\
Modify the internal transfer price & Tax-credit $_{p}=1$ & $\checkmark$ & $\times$ \\
\hline
\end{tabular}

Notes:

(i) $\Delta \mathrm{CIT}_{E c e}=$ Corporate income tax $\mathrm{Ecuador}$ - Corporate income tax ${ }_{\text {Exporter country }}$.

(ii) $\psi_{p e}$ is the import taxation rate (excluding VAT and the capital outflow tax) of the HS-10 product $p$ coming from the exporter country $e$.

(iii) Tax-credit $p$ equals one if the HS-10 product $p$ is eligible to the tax-credit measure on the capital outflow tax and zero otherwise.

(iv) The internal transfer price is the customs declared value.

(v) The sample is formed by imports from (20) top source countries of foreign direct investment into Ecuador having signed a double taxation agreement (with Ecuador); imports from tax havens or very low-tax jurisdictions are excluded.

(vi) " $\checkmark$ " indicates that the condition is satisfied. " $\times$ " indicates that the condition is not met.

consider resolutions CPT-07-2012 and CPT-02-2013 as a single resolution, we exclude from the sample import declarations registered in January. Furthermore, we exclude imports through land borders since informal trade is a non-negligible phenomenon across Ecuadorian land borders ${ }^{38}$. Moreover, for comparability purposes, the sample is restricted to HS-10 products whose the quantity unit used is the weight. It is worth mentioning that the weight, usually expressed in kilograms $(\mathrm{kg})$, is the most widely quantity unit used. Finally, in order to get a constant composition of each group over the period, we restrict the sample to HS10 products coming from a particular country imported each year -i.e., one observation before and one observation after the tax-credit measure ${ }^{39}$. The final sample includes 686 observations - 300 treated and 386 control observations - and accounts for $1.2 \%$ of the total imported value. Table 4 displays the number of HS-10 products exported to Ecuador by trading partner. Summary statistics for the unit value by group are displayed in table 9 , Appendix A. In subsection 4.4, we will discuss potential threats to identification.

\subsection{Econometric specification}

We use a linear difference-in-difference method to estimate how the over-reporting incentive (the tax-measure) affected the declared unit value,

Unit value $_{p e t}=\alpha+\beta$ Tax-credit $_{p}+\gamma$ PostResolution $_{t}+\eta$ Tax-credit PostResolution $_{p t}+\mathbf{X}_{\text {pet }^{\prime}}^{\prime} \phi+\epsilon_{\text {pet }}$

where $\mathrm{p}$ indexes the HS-10 product, e indexes the exporter country and $\mathrm{t}$ indexes time. The unit of observation is a HS-10 product-exporting country annual import flow. $\alpha$ is the constant term and $\epsilon_{p e t}$ is the error term. The declared value-to-quantity ratio (in logarithm)

\footnotetext{
${ }^{38}$ On informal trade across Ecuador's land borders, the reader may consult the ongoing Inter-American Development Bank (IADB) project "Improvement of border crossings in Ecuador".

${ }^{39} \mathrm{~A}$ robustness check will relax this latest sample restriction.
} 
Table 4: Basic statistics by trading partner, final sample

\begin{tabular}{llllllllll}
\hline Country & $\Delta C I T$ & Tax rate & Tax rate & \# HS10 & \# HS10 & Share (\# HS10) & Share (\# HS10) & Share (value) & Share (value) \\
\hline Sample & All & Treated & Control & Treated & Control & Treated & Control & Treated & Control \\
\hline Canada & $2.7 \%$ & $0.5 \%$ & $0.5 \%$ & 1 & 1 & $0.7 \%$ & $0.5 \%$ & $2.6 \%$ & $0.5 \%$ \\
Chile & $13.7 \%$ & $0.5 \%$ & $1.6 \%$ & 33 & 57 & $22.0 \%$ & $29.5 \%$ & $69.2 \%$ & $41.7 \%$ \\
Colombia & $8.7 \%$ & $0.5 \%$ & $0.6 \%$ & 3 & 3 & $2.0 \%$ & $1.6 \%$ & $7.4 \%$ & $7.6 \%$ \\
Germany & $18.7 \%$ & $9.0 \%$ & $10.4 \%$ & 84 & 100 & $56.0 \%$ & $51.8 \%$ & $14.1 \%$ & $18.2 \%$ \\
Italy & $6.2 \%$ & $2.8 \%$ & $1.2 \%$ & 13 & 9 & $8.7 \%$ & $4.7 \%$ & $4.1 \%$ & $5.4 \%$ \\
Mexico & $3.7 \%$ & $1.8 \%$ & $0.5 \%$ & 2 & 2 & $1.3 \%$ & $1.0 \%$ & $0.4 \%$ & $12.6 \%$ \\
Peru & $3.7 \%$ & $0.5 \%$ & $0.5 \%$ & 12 & 20 & $8.0 \%$ & $10.4 \%$ & $0.9 \%$ & $12.8 \%$ \\
Spain & $3.7 \%$ & $1.0 \%$ & $0.5 \%$ & 2 & 1 & $1.3 \%$ & $0.5 \%$ & $1.2 \%$ & $1.1 \%$ \\
\hline
\end{tabular}

Notes:

(i) $\triangle$ CIT is the corporate income tax rate differential.

(i) Tax rate is the import taxation rate (excluding VAT).

(ii) \# HS10 is the number of HS-10 products in the final sample.

(iii) Share (\# HS10) is the fraction of HS-10 products coming from the country.

(iv) Share (\# HS10) is the sum of imports (expressed in USD) coming from the country divided by total imports (expressed in USD).

(v) All these countries have signed a double taxation agreement with Ecuador and belong to the top 20 source countries of foreign direct investment into Ecuador.

Unit value is the outcome of interest ${ }^{40}$.

The Tax-credit variable is coded as one if the product $p$ coming from the exporting country $e$ is in the tax-credit list and zero otherwise; PostResolution is a dummy where 0 indicates a time period before the treatment group receives treatment (year 2012) and 1 indicates a time period after the treatment group receives treatment (year 2013); and the interaction term between the two variables - Tax-credit $\times$ PostResolution- captures the difference-in-difference treatment effect ${ }^{41}$. According to the empirical literature on customs evasion, customs evasion is tariff-varying. To control for such differences in enforcement, we therefore add the import taxation rate (excluding VAT) and the VAT rate as covariates ${ }^{42}$. The vector of taxation variables is $\mathbf{X}^{\prime}$. While $\beta$ represents initial differences between treatment and comparison groups, $\gamma$ says whether outcomes evolve over time. The coefficient $\eta$ is the treatment effect and captures the difference-in-differences between the unit value for the treated and control groups, before and after the resolution. To correct the potential bias in the estimated standard errors due to serial correlation, we follow Bertrand, Duflo, and Mullainathan (2004)'s recommendations. Firstly, we aggregate data on an annual basis (2012 is the pre-period, 2013 is the post-period), solving the problem of seasonality of imports. This problem arises when products are not imported during certain seasons or when prices vary seasonally. Secondly, we cluster standard errors at various (sub)group levels (HS-2 digit, HS-4 digit or HS-6 digit) to allow for within correlation in the unit value.

\footnotetext{
${ }^{40}$ Unit value is expressed in USD per kilogram, on a c.i.f basis.

${ }^{41}$ Bear in mind that the double difference estimator is mainly based on the following two assumptions: (i) selection bias and other sources of errors are separable and time invariant, (ii) outcomes before the measure implementation are not contaminated by an expectation of future treatment, see Ravallion (2007).

${ }^{42}$ Notice that imports with a time-varying import taxation rate are excluded from the sample.
} 


\subsection{Causality, identifying assumption and checks}

The identification strategy relies on the key assumption that, in the absence of an incentive to over-report, the treatment and the control group followed the same unit value trend. More formally, it means that, if the error term is correlated with explanatory variables conditional on the list of controls, then the estimation of the causal effect is biased $\left(\hat{\eta}_{D D} \neq \eta\right.$ with $\hat{\eta}_{D D}$ the double difference estimator).

A first way to test the plausibility of this assumption is to check if the treatment and the comparison group followed a common trend. In the figure 3, using quarterly data, we plot time trends of the declared unit value for eligible products (i.e., the treatment group) and non eligible products (i.e., the comparison group). First, we observe that the declared unit values (in log) for the treatment and the comparison group are at the beginning and end of the pre-resolution period (year 2012) extremely close. Then, the graph highlights a sudden change in the declared unit value just after the introduction of the tax-credit measure for the treatment group (first quarter of 2013). This suggests that importers exploited the opportunity to escape the tax on capital outflows. Finally, notice that during the remainder of 2013, unit values followed exactly the same trends suggesting that (other) shocks probably affected in the same way treatment and control groups.

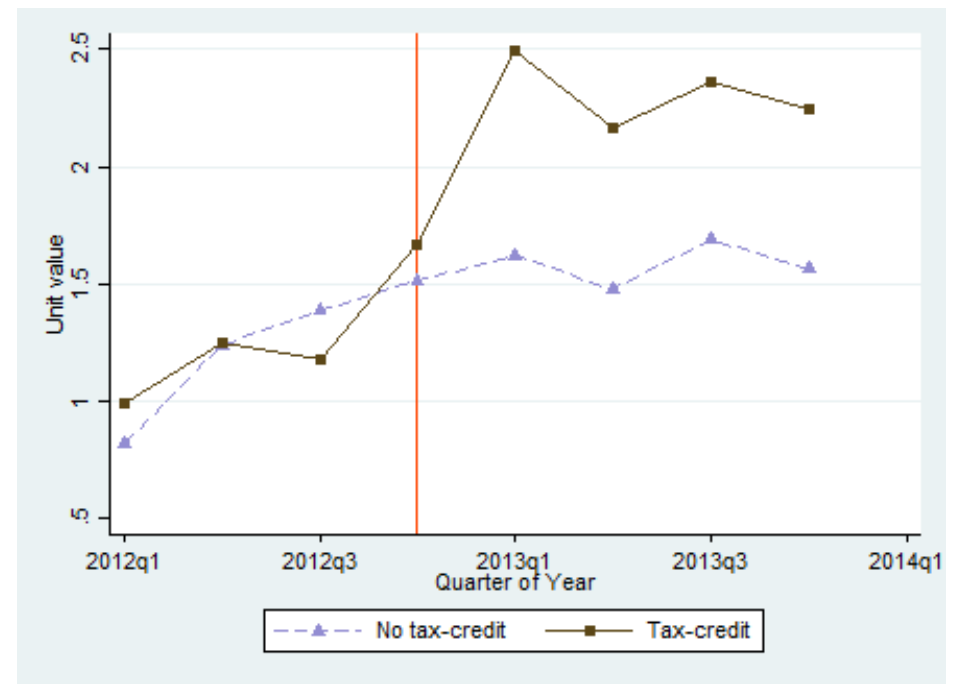

Figure 3: Evolution of the declared unit value

\footnotetext{
Observations: the treatment group is formed by HS-10 products (i) eligible to the tax credit measure, (ii) with an import taxation rate (excluding VAT) smaller than the corporate income tax differential and (iii) coming from a country listed in table 4. The control group is formed by HS-10 products (i) non eligible to the tax credit measure, (ii) with an import taxation rate (excluding VAT) smaller than the corporate income tax differential and (iii) coming from a country listed in table 4. Unit value $=\operatorname{Ln}($ value-to-quantity-ratio). The vertical line denotes the start of the tax-credit measure. Database source: customs data from the SENAE.
}

Potential confounding factors during the treatment period are an important concern to 
a causal interpretation. Indeed, if the emergence of an incentive to over-report coincides with some other factors - e.g. a specific sudden large increase in import prices - that are in fact responsible for the declared unit value increase, then difference-in-differences estimates are biased. The appropriate definition of the control group aims at preventing unobservable confounding factors. Since all treated observations are closely associated with at least one control observation ${ }^{43}$, intrinsic characteristics between the treatment group and the comparison group are thus fairly close (see table 10, Appendix A). Additional statistics will support this argument (see below). Furthermore, notice that treatment and control groups share de facto some similar unobservable characteristics (e.g. some transfer pricing characteristics). Remind also that figure 3 indicates that treatment and comparison groups seem to be affected by similar shocks. Therefore, a change in the declared unit value affecting only the treatment group due to unobservable factors seems highly unlikely.

As for observable variables, statistics displayed in table 5 outline that treatment and control groups are quite similar in terms of product characteristics - products are largely differentiated according to the Rauch classification of goods and quite sophisticated according to the Hausmann-Hidalgo product complexity index ${ }^{44}$ - and shipment characteristics — no prevalence of sea shipping and a little transit through the United States are observed-. Note also that, whatever the group considered, a large part of imported products serve as inputs for industrial production (more than 75\%) suggesting a prevalence of the intra-firm trade. In order to identify possible observable confounding factors, the last column presents, for each time-varying variable, the coefficient estimated by running a basic difference-in-differences regression ${ }^{45}$. Results do not indicate significant changes.

\section{Empirical results}

\subsection{Preliminary evidence}

Our empirical strategy compares trends in the declared unit value for eligible versus noneligible imports before and after the tax-credit resolution. Figure 4 presents for each group the evolution of the average declared unit value. Consistently with our expectations, an increase in the declared unit value is only observed for the treatment group.

\footnotetext{
${ }^{43}$ It means that at least one non-eligible HS-10 product and one eligible HS-10 product are classified in the same section.

${ }^{44}$ The Rauch classification of goods classifies goods as homogeneous or differentiated. Whereas an homogenous good, a differentiated good (e.g. a jacket) is a good not having a reference price or not quoted on an organized exchange, the database is available at the following address: http://www.macalester. edu/research/economics/PAGE/HAVEMAN/Trade.Resources/TradeData.html. In our study, the variable Differentiated product is one if the product is differentiated and zero otherwise. The Product Complexity Index (PCI) classifies "goods by the estimated amount of capabilities or know-how necessary to manufacture them", see the "The Atlas of Economic Complexity", http://www.atlas.cid.harvard.edu. A large PCI means that the product is complex. The PCI value is for both groups larger than the mean $(0.000)$ and the median (0.139) but slightly lower than the third quartile (0.740) of the 2012 PCI database. Finally, note that Rauch classification data and (2012) PCI data are respectively at the SITC-4 digit level and at the HS-4 digit level.

${ }^{45}$ Standard errors are clustered at the HS-6 product level.
} 
Table 5: Observable characteristics of treatment and control groups

\begin{tabular}{|c|c|c|c|c|c|c|c|c|c|}
\hline & & Treatm & nt group & & & Contro & l group & & \\
\hline & Pre-period & & Post-period & & Pre-period & & Post-period & & Difference-in \\
\hline & Mean & S.D. & Mean & S.D. & Mean & S.D. & Mean & S.D. & differences \\
\hline Sample & & & & & & & & & \\
\hline $\mathrm{N}($ total $=686)$ & 150 & & 150 & & 193 & & 193 & & \\
\hline Share & 0.219 & & 0.219 & & 0.281 & & 0.281 & & \\
\hline Dependent variable & & & & & & & & & \\
\hline Unit value, cif & 2.662 & 1.323 & 2.879 & 1.324 & 2.624 & 1.525 & 2.577 & 1.498 & $0.264^{* *}(0.133)$ \\
\hline Unit value, fob & 2.566 & 1.323 & 2.760 & 1.329 & 2.505 & 1.523 & 2.485 & 1.504 & $0.214^{*}(0.128)$ \\
\hline Shipment characteristics & & & & & & & & & \\
\hline Arrival by air & 0.503 & 0.339 & 0.477 & 0.331 & 0.435 & 0.388 & 0.362 & 0.374 & $0.048(0.039)$ \\
\hline Arrival by sea & 0.497 & 0.339 & 0.523 & 0.331 & 0.565 & 0.388 & 0.638 & 0.374 & $-0.048(0.039)$ \\
\hline Transit through the USA & 0.068 & 0.104 & 0.064 & 0.117 & 0.072 & 0.131 & 0.053 & 0.131 & $0.015(0.013)$ \\
\hline Product characteristics (ti & & & & & & & & & \\
\hline Capital good & 0.087 & 0.282 & & & 0.062 & 0.242 & & & \\
\hline Intermediate good & 0.867 & 0.341 & & & 0.756 & 0.430 & & & \\
\hline Consumption good & 0.033 & 0.180 & & & 0.161 & 0.368 & & & \\
\hline Price Complexity Index & 0.854 & 0.639 & & & 0.478 & 0.601 & & & \\
\hline Differentiated product & 0.743 & 0.439 & & & 0.851 & 0.357 & & & \\
\hline Taxation & & & & & & & & & \\
\hline Tax rate (no VAT) & 0.072 & 0.060 & 0.072 & 0.062 & 0.067 & 0.063 & 0.068 & 0.062 & $-0.002(0.003)$ \\
\hline VAT rate & 0.124 & 0.023 & 0.123 & 0.025 & 0.125 & 0.021 & 0.124 & 0.022 & $0.000(0.002)$ \\
\hline
\end{tabular}

Notes:

(i) Observations are at the HS-10 product-trade partner year level.

(ii) It is not surprising that the effective VAT rate on imports could be larger than the standard VAT rate $(12 \%)$. Indeed, the tax base of VAT is the customs value plus trade taxes. The formula is the following:

VAT paid on imports $=$ Declared import value ${ }_{\text {c.i.f }} \times(1+$ trade tax rate $) \times($ standard VAT rate $)$. If there exists some trade taxes, the VAT rate paid on imports is thus larger than the standard rate.

(iii) The difference-in-differences coefficient is statistically significant from zero at the *** $1 \%, * * 5 \%$ and $*$ $10 \%$ level. The ordinary least squares estimator is used. 


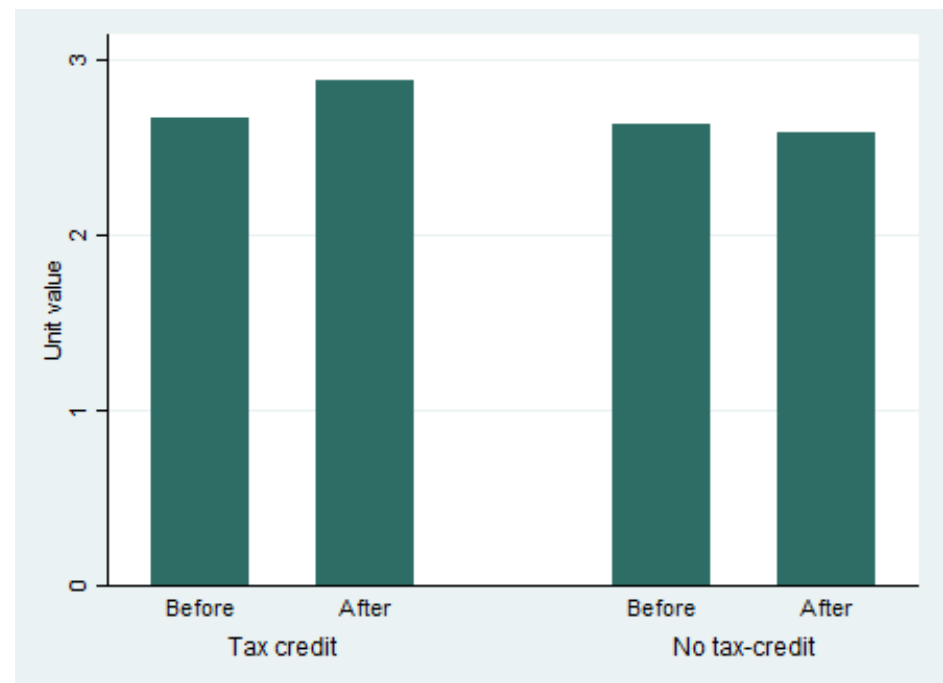

Figure 4: Change of the declared unit value

Observations: the treatment (Tax credit) group is formed by HS-10 products (i) eligible to the tax credit measure, (ii) with an import taxation rate (excluding VAT) smaller than the corporate income tax differential and (iii) coming from a country listed in table 4. The control group is formed by HS-10 products (i) non eligible to the tax credit measure, (ii) with an import taxation rate (excluding VAT) smaller than the corporate income tax differential and (iii) coming from a country listed in table 4 . Unit value $=\operatorname{Ln}$ (value-to-quantity-ratio). Database source: customs data from the SENAE.

\subsection{Baseline results and analysis}

Table 6 presents the regression results of equation 1 without (columns 1-3) or with (columns 4-6) the inclusion of taxation variables. Throughout all regressions, the dependent variable is the declared unit value (in logarithm). As previously mentioned, we correct the conventional standard errors by taking into account clustering at various levels (HS-6 digit, HS-4 digit, HS-2 digit), see Imbens and Wooldridge (2009). Estimated coefficients are presented in bold. Clustered standard errors are in parentheses. Let us first discuss (baseline) results presented in column 1.

Before the introduction of the tax-credit measure, the declared unit value of the treatment group was, on average, not significantly different from the declared unit value of the comparison group (see row 3). Estimates also indicate non significant changes in the unit price of imports between 2012 and 2013 (see row 7). This notably suggests no changes in the transfer price of imports belonging to the control group. The estimated coefficient associated with Taxcredit $\mathrm{x}$ PostResolution captures the unconditional difference-in-differences between the declared unit value (in logarithm) for the treatment and control groups, before and after the resolution. The coefficient of the interaction term is positive and statistically significant suggesting that importers over-reported (eligible) imports in order to escape the capital outflow tax. The effect is sizeable: the incentive to over-report increased the unit value by $26 \%$. Notice that, regardless of the level of clustering (HS-6 or HS-4 or HS-2 digit), statistical significance holds. Finally, it is worth mentioning that results are not affected by 
(i) a change in the incoterm used (f.o.b in place of c.i.f, columns 2 and 5), (ii) the exclusion of imports from neighbouring countries (Peru and Colombia, columns 3 and 6) and (iii) the inclusion of tax variables (columns 4-6).

To check the robustness of our results to the balance sample choice, we re-estimate equation 1 using an unbalanced sample. The restriction that a HS-10 product coming from a particular country must be imported before and after the treatment is thus relaxed. Since single observation data are included, the sample size obviously increases (68 additional observations). It is noteworthy that not removing unbalanced data implies that the composition of each group changes over time. Therefore, in order to mitigate the composition change effect, we include in the baseline specification HS-2 industry and trade partner dummies. Estimated coefficients of interest, displayed in table 11, Appendix A are statistically significant and similar in magnitude with those reported in the previous table.

\section{Capital flight or profit-shifting?}

\subsection{Capital flight from Ecuador and resident firms' strategy}

Capital flight from Latin America remains a heavy issue in Latin America (see e.g. Pastor (1990)). In Ecuador, the dollarization and the relative financial openness facilitate capital flight. Kar and Cartwright-Smith (2008) estimate that Ecuador looses, each year, USD \$1.37 billions representing $1.4 \%$ of the GDP.

Since trade mis-invoicing is a well-known channel for moving capital to more promising locations (see e.g. Brada, Kutan, and Vukšić (2013)), the tax-credit measure may have also created an incentive for national firms to over-report eligible imports in order to move their capital abroad (to flight capital). Consequently, the increase in the declared unit value previously fund may be (at least partially) attributable to a potential resident firms' response.

To address this concern, we carry out some investigations in order to determine whether the increase in the declared value is attributable to a profit shifting or capital flight behavior. Support to the hypothesis that the increase is attributable to MNEs is provided. Firstly, we show that the increase in the declared unit value is only found for imports from countries listed in table 4 - i.e. originating from top investors countries having signed a tax treaty with Ecuador. Then, we stress that results are highly dependent on the profit-shifting condition $(\Delta \mathrm{CIT}>\psi)$. Finally, using discrepancies in mirror statistics, our final estimates reinforce the hypothesis that the increase does not come from a capital flight behavior.

\subsection{Sensitivity analysis}

\subsubsection{Sensitivity to the choice of trading partners}

We continue to restrict the sample to imports coming from a low-CIT country and subject to an import taxation rate (excluding VAT) lower than the corporate income tax rate differential. Yet, to test whether the tax-credit measure has differently impacted the declared 
Table 6: Baseline results

\begin{tabular}{lllllll}
\hline Variables & Unit value & Unit value & Unit value & Unit value & Unit value & Unit value \\
\hline & $(1)$ & $(2)$ & $(3)$ & $(4)$ & $(5)$ & $(6)$ \\
\hline Taxcredit & $\mathbf{0 . 0 3 9}$ & $\mathbf{0 . 0 6 1}$ & $\mathbf{0 . 0 0 5}$ & $\mathbf{0 . 0 0 1}$ & $\mathbf{0 . 0 2 5}$ & $\mathbf{- 0 . 0 2 2}$ \\
Cluster HS6 & $(0.191)$ & $(0.193)$ & $(0.192)$ & $(0.197)$ & $(0.200)$ & $(0.199)$ \\
Cluster HS4 & $(0.189)$ & $(0.191)$ & $(0.193)$ & $(0.196)$ & $(0.200)$ & $(0.199)$ \\
Cluster HS2 & $(0.158)$ & $(0.160)$ & $(0.178)$ & $(0.173)$ & $(0.177)$ & $(0.192)$ \\
PostResolution & $\mathbf{- 0 . 0 4 7}$ & $\mathbf{- 0 . 0 2 0}$ & $\mathbf{- 0 . 0 2 6}$ & $\mathbf{- 0 . 0 5 7}$ & $\mathbf{- 0 . 0 2 9}$ & $\mathbf{- 0 . 0 3 5}$ \\
Cluster HS6 & $(0.093)$ & $(0.095)$ & $(0.101)$ & $(0.090)$ & $(0.093)$ & $(0.098)$ \\
Cluster HS4 & $(0.083)$ & $(0.087)$ & $(0.087)$ & $(0.082)$ & $(0.086)$ & $(0.086)$ \\
Cluster HS2 & $(0.098)$ & $(0.104)$ & $(0.107)$ & $(0.094)$ & $(0.100)$ & $(0.103)$ \\
TaxcreditxPostResolution & $\mathbf{0 . 2 6 4}$ & $\mathbf{0 . 2 1 4}$ & $\mathbf{0 . 2 4 4}$ & $\mathbf{0 . 2 7 7}$ & $\mathbf{0 . 2 2 6}$ & $\mathbf{0 . 2 5 6}$ \\
Cluster HS6 & $(0.134)^{*}$ & $(0.132)^{\mathrm{a}}$ & $(0.146)^{*}$ & $(0.133)^{* *}$ & $(0.131)^{*}$ & $(0.145)^{*}$ \\
Cluster HS4 & $(0.133)^{* *}$ & $(0.128)^{*}$ & $(0.143)^{*}$ & $(0.134)^{* *}$ & $(0.128)^{*}$ & $(0.145)^{*}$ \\
Cluster HS2 & $(0.109)^{* *}$ & $(0.112)^{*}$ & $(0.128)^{*}$ & $(0.110)^{* *}$ & $(0.112)^{*}$ & $(0.129)^{*}$ \\
Constant & $\mathbf{2 . 6 2 4}$ & $\mathbf{2 . 5 0 5}$ & $\mathbf{2 . 7 6 0}$ & $\mathbf{2 . 1 9 3}$ & $\mathbf{2 . 1 0 4}$ & $\mathbf{2 . 3 0 9}$ \\
Cluster HS6 & $(0.146)^{* * *}$ & $(0.147)^{* * *}$ & $(0.146)^{* * *}$ & $(0.460)^{* * *}$ & $(0.445)^{* * *}$ & $(0.671)^{* * *}$ \\
Cluster HS4 & $(0.160)^{* * *}$ & $(0.160)^{* * *}$ & $(0.159)^{* * *}$ & $(0.516)^{* * *}$ & $(0.498)^{* * *}$ & $(0.755)^{* * *}$ \\
Cluster HS2 & $(0.262)^{* * *}$ & $(0.271)^{* * *}$ & $(0.266)^{* * *}$ & $(0.602)^{* * *}$ & $(0.579)^{* * *}$ & $(0.899)^{* * *}$ \\
\hline Incoterm & $\mathrm{CIF}$ & $\mathrm{FOB}$ & $\mathrm{CIF}$ & $\mathrm{CIF}$ & $\mathrm{FOB}$ & CIF \\
Tax variables & No & No & No & Yes & Yes & Yes \\
Observations & 686 & 686 & 610 & 686 & 686 & 610 \\
R-squared & 0.006 & 0.005 & 0.005 & 0.111 & 0.096 & 0.078 \\
\hline
\end{tabular}

Notes:

(i) Observations are at the HS-10 product-trade partner-year level.

(ii) The dependent variable is the Unit value $=\ln ($ Declared unit value). The incoterm is cost insurance and freight (CIF) or free on board (FOB).

(iii) The sample used for regressions 1-2 and 4-5 is 'DTA'. The sample used for regressions 3 and 6 is 'No neighbours'. The sample 'DTA' is formed by imports (i) with an import taxation rate (excluding VAT) lower than the corporate income tax differential (ii) coming from 20 top source countries of foreign direct investment into Ecuador and (iii) originating from a country having signed a double taxation agreement with Ecuador ; imports from tax havens or very low-tax jurisdictions are excluded. The sample 'No neighbours' is formed by imports (i) with an import taxation rate (excluding VAT) lower than the corporate income tax differential (ii) coming from 20 top source countries of foreign direct investment into Ecuador and (iii) originating from a country having signed a double taxation agreement with Ecuador ; imports from neighbours countries, tax havens or very low-tax jurisdictions are excluded.

(iv) Coefficients are in bold, the row Cluster HS-6 presents standard errors clustered at the HS-6 digit level, the row Cluster HS-4 presents standard errors clustered at the HS-4 digit level, the row Cluster HS-2 presents standard errors clustered at the HS-2 digit level.

(v) The coefficient is statistically significant from zero at the ${ }^{* *} 1 \%, * * 5 \%, * 10 \%$ and $a 15 \%$ level.

(vi) We use the ordinary least squares estimator. 
unit value according to the exporting country, we divide trading partners into two groups. While the 'DTA' group (the sample used until now) is formed by top investors countries having signed a tax treaty with Ecuador, the 'No DTA' group consists of all other trading partners.

Table 7 presents regression results. The import value is expressed c.i.f in columns 13 and f.o.b in columns 4-6. In column 1, the total sample is considered (i.e., all groups are included). The estimated coefficient, significant at $15 \%$, indicate that the tax-credit measure is associated with an increase in the declared unit value. Then, we split countries into groups. We observe that the coefficient of interest is higher and statistically significant at the 5\%/10\% level for the 'DTA' group, see column (2). This result does not hold for the 'No DTA' group: estimates are not significant and the coefficient is extremely small, see column (3). The "global" effect presented in column (1) is therefore driven by imports originating from countries repatriating a lot of funds from Ecuadorian operations. Such differentiated impacts support the profit-shifting hypothesis. Results are unaffected when the import value is expressed free-on-board, see columns 4-6. Consistently with the profit shifting hypothesis, note also that, by gradually restricting the sample to products coming from top investors countries having signed a tax treaty, we observe that estimated coefficients and significance increase gradually as the sample approaches the 'DTA' sample, see table 13, Appendix A ${ }^{46}$.

\subsubsection{Sensitivity to the incentive to shift profits}

As mentioned in section 4, shifting profits is interesting for multinationals if and only if the corporate income tax differential $(\Delta \mathrm{CIT}$ ) is larger than taxes on imports (excluding VAT, $\psi$ ). This international tax planning condition is useless for national firms wishing to engage in a capital flight behavior. Exploiting the fact that capital flight behaviors are independent to the international tax planning condition, we can therefore test to what extent results previously fund are due to a capital flight behavior or a profit shifting behavior.

Table 14, Appendix A outlines that, when the international tax planning condition is not met-i.e., $\psi>\Delta$ CIT -, estimates do not indicate an abnormal increase in the declared unit value. Estimated coefficients are non significant, negative and small; for the 'DTA' sample, see column $4^{47}$. Since results are highly sensitive to the international tax planning condition, it therefore suggests that the increase in the declared unit value is attributable to a profit-shifting behavior.

\subsection{Use of discrepancies in bilateral trade statistics}

\subsubsection{Mirror trade statistics}

Mirror trade statistics are annual merchandise trade flows reported by trading partners to the UN Statistics Division (UNSD). Based on these, discrepancies in trade statistics -

\footnotetext{
${ }^{46}$ The number of observations by trading partner is presented in table 12, Appendix A.

${ }^{47}$ Notice also that by gradually restricting the sample to products coming from top investors countries having signed a tax treaty, estimated coefficients of interest do not vary.
} 
Table 7: Sensibility to the sample choice

\begin{tabular}{lllllll}
\hline Variables & Unit value & Unit value & Unit value & Unit value & Unit value & Unit value \\
\hline Taxcredit & $(1)$ & $(2)$ & $(3)$ & $(4)$ & $(5)$ & $(6)$ \\
Cluster HS6 & $\mathbf{- 0 . 0 1 9}$ & $\mathbf{0 . 0 3 9}$ & $\mathbf{- 0 . 0 9 3}$ & $\mathbf{- 0 . 0 2 6}$ & $\mathbf{0 . 0 6 1}$ & $\mathbf{- 0 . 1 2 1}$ \\
Cluster HS4 & $(0.280)$ & $(0.191)$ & $(0.392)$ & $(0.288)$ & $(0.193)$ & $(0.405)$ \\
Cluster HS2 & $(0.284)$ & $(0.189)$ & $(0.407)$ & $(0.294)$ & $(0.191)$ & $(0.420)$ \\
PostResolution & $(0.242)$ & $(0.158)$ & $(0.315)$ & $(0.259)$ & $(0.160)$ & $(0.340)$ \\
Cluster HS6 & $\mathbf{- 0 . 0 4 8}$ & $\mathbf{- 0 . 0 4 7}$ & $\mathbf{- 0 . 0 5 0}$ & $\mathbf{- 0 . 0 2 5}$ & $\mathbf{- 0 . 0 2 0}$ & $\mathbf{- 0 . 0 3 0}$ \\
Cluster HS4 & $(0.058)$ & $(0.093)$ & $(0.070)$ & $(0.061)$ & $(0.095)$ & $(0.073)$ \\
Cluster HS2 & $(0.052)$ & $(0.083)$ & $(0.064)$ & $(0.055)$ & $(0.087)$ & $(0.066)$ \\
TaxcreditxPostResolution & $\mathbf{0 . 1 4 5}$ & $\mathbf{0 . 2 6 4}$ & $\mathbf{0 . 0 6 3}$ & $\mathbf{0 . 1 4 0}$ & $\mathbf{0 . 2 1 4}$ & $\mathbf{0 . 0 9 1}$ \\
Cluster HS6 & $(0.094) \mathrm{a}$ & $(0.134)^{*}$ & $(0.121)$ & $(0.097) \mathrm{a}$ & $(0.132) \mathrm{a}$ & $(0.129)$ \\
Cluster HS4 & $(0.093) \mathrm{a}$ & $(0.133)^{* *}$ & $(0.133)$ & $(0.096) \mathrm{a}$ & $(0.128)^{*}$ & $(0.135)$ \\
Cluster HS2 & $(0.112)$ & $(0.109)^{* *}$ & $(0.154)$ & $(0.116)$ & $(0.112)^{*}$ & $(0.159)$ \\
Constant & $\mathbf{2 . 8 5 9}$ & $\mathbf{2 . 6 2 4}$ & $\mathbf{3 . 0 5 6}$ & $\mathbf{2 . 7 4 7}$ & $\mathbf{2 . 5 0 5}$ & $\mathbf{2 . 9 5 0}$ \\
Cluster HS6 & $(0.252)^{* * *}$ & $(0.146)^{* * *}$ & $(0.362)^{* * *}$ & $(0.259)^{* * *}$ & $(0.147)^{* * *}$ & $(0.372)^{* * *}$ \\
Cluster HS4 & $(0.255)^{* * *}$ & $(0.160)^{* * *}$ & $(0.369)^{* * *}$ & $(0.262)^{* * *}$ & $(0.160)^{* * *}$ & $(0.379)^{* * *}$ \\
Cluster HS2 & $(0.349)^{* * *}$ & $(0.262)^{* * *}$ & $(0.422)^{* * *}$ & $(0.358)^{* * *}$ & $(0.271)^{* * *}$ & $(0.433)^{* * *}$ \\
\hline Incoterm & CIF & CIF & CIF & FOB & FOB & FOB \\
Sample & All & DTA & No DTA & All & DTA & No DTA \\
Observations & 1,584 & 686 & 898 & 1,584 & 686 & 898 \\
R-squared & 0.001 & 0.006 & 0.001 & 0.001 & 0.005 & 0.001 \\
\hline
\end{tabular}

Notes:

(i) Observations are at the HS-10 product-trade partner-year level.

(ii) The dependent variable is the Unit value $=\ln$ (Declared unit value). The incoterm is cost insurance and freight (CIF) or free on board (FOB).

(iii) The sample 'All' is formed by imports (i) with an import taxation rate (excluding the VAT) lower than the corporate income tax differential and (ii) not coming from a tax haven or a very low-tax jurisdiction. The sample 'DTA' is formed by imports (i) with an import taxation rate (excluding the VAT) lower than the corporate income tax differential (ii) coming from 20 top source countries of foreign direct investment into Ecuador and (iii) originating from a country having signed a double taxation agreement with Ecuador ; imports from tax havens or very low-tax jurisdictions are excluded. The sample 'No DTA' is formed by imports (i) with an import taxation rate (excluding the VAT) lower than the corporate income tax differential, (ii) not coming from a tax haven or a very low-tax jurisdiction and (iii) not present in the sample 'DTA'.

(iv) Coefficients are in bold, the row Cluster HS-6 presents standard errors clustered at the HS-6 digit level, the row Cluster HS-4 presents standard errors clustered at the HS-4 digit level, the row Cluster HS-2 presents standard errors clustered at the HS-2 digit level.

(v) The coefficient is statistically significant from zero at the *** $1 \%,{ }^{* *} 5 \%,{ }^{*} 10 \%$ and $a 15 \%$ level.

(vi) We use the ordinary least squares estimator. 
i.e. the difference between the export value and the import value - can be computed on an annual basis. These discrepancies are increasingly used as a proxy for customs fraud ${ }^{48}$.

\subsubsection{Empirical strategy}

The identification strategy exploits that fact that relying on the transfer pricing technique to shift profits does not create discrepancies in trade statistics - i.e., the difference between the recorded export value and the recorded import value remains constant. Indeed, since the export declaration and the import declaration are similar when a MNE uses transfer prices for tax evasion purposes, we therefore argue that discrepancies in trade statistics are not affected by the tax-credit measure. It implies that a sudden (change in the) manipulation of transfer prices does not impact the difference between the recorded export value and the recorded import value. Regarding unrelated-party transactions, a resident firm wishing to move money abroad probably makes an import declaration different from the export declaration made by the exporter. Under the assumption of no collusion between the exporter and the importer, such a behavior creates discrepancies This implies that while the tax-credit measure incentivizes the importer to over-report, tax-credits do not create an incentive to misreport for the exporter which ultimately generates discrepancies. The identification strategy relies on the assumption that, for not related-party trade, export declarations and import declarations are made independently. To sum-up, if resident firms illegally exploited the taxcredit measure to escape the tax on capital outflows, then we expect a decline in the trade gap -i.e., the export value minus the import value- for eligible products ${ }^{49}$. In order to test this hypothesis, we will therefore run an OLS regression of the form:

Unit value gap $_{g e t}=\alpha_{m}+\beta_{m}$ Taxcredit $_{g e}+\gamma_{m}$ PostResolution $_{t}+\eta_{m}$ Taxcredit $\times$ PostResolution $_{\text {get }}$

$$
+\mathbf{X}_{\text {get }}^{\prime} \phi_{\mathbf{m}}+v_{\text {get }}
$$

where Unit value gap get $=\ln \left(\frac{\text { Registered unit export value }_{\text {get }}}{\text { Registered unit import value }_{g e t}}\right)$ is the measure of discrepancies ${ }^{50}$; the subscript $m$ strands for the mirror statistics specification; $g$ indexes the HS-6 good and $v_{\text {pet }}$ is the error term. The Unit value gap is the difference (in $\log$ ) between the value of exports from each trade partner to Ecuador as reported by each trade partner and the value of imports by Ecuador from each trade partner as reported by Ecuador. Dependent variables remain unchanged, see definition in subsection 4.3. Exports data, expressed in USD\$, come from the UN COMTRADE database. Since export data, are at the HS-6 digit level, we have to aggregate import data on a HS 6-digit basis. The unit of observation is a HS-6 producttrade partner-year triplet. As with other papers using discrepancies in trade statistics, the

\footnotetext{
${ }^{48}$ Discrepancies in trade statistics are useful to detect some misvaluations (see Ferrantino, Liu, and Wang (2012), Mishra, Subramanian, and Topalova (2008), Rijkers, Baghdadi, and Raballand (2015)) and misclassifications (see Fisman and Wei (2004)) practices. For data accuracy issues, see e.g. Chalendard, Raballand, and Rakotoarisoa (2016).

${ }^{49} \mathrm{We}$ assume no change in the exporter declaration behavior.

${ }^{50}$ In order to reduce the problem of non-normality of the residuals, the logarithmic form is used.
} 
match rate between imports and exports is imperfect -i.e., not equal to one - hence a smaller number of observations. The treatment group is formed by HS-6 goods for which all corresponding HS-10 products are eligible to the tax-credit measure. Following sample and data restrictions specified in section 4, we get a sample formed by 642 observations.

\subsubsection{Results}

For comparability purposes with baseline estimates, table 8 first presents, in columns (1)-(2), regression results found in estimating equation 1 based on the new final sample. Estimates confirm a positive increase in the declared value for HS-6 goods eligible to the tax-credit measure. The estimated size (22\%, see columns 1-2) is close to that presented in table $6(26 \%$, column 1$)$ indicating that our sample at the HS-6 digit level is representative of the sample at the HS-10 digit level described in subsection 4.4.

The regression results using the Unit value gap as dependent variable are displayed in columns (3)-(4), table 8. The estimated coefficient associated with Tax credit x PostResolution is not statistically significant — the associated p-value is close to 0.50 - The lack of significance points that the tax-credit measure has not significantly induced a change in discrepancies. In turn, this suggests that resident firms engaging in capital flight used alternative tax-evasion/capital flight methods or simply did not escape the tax on capital outflows ${ }^{51}$. These estimates therefore suggest that the increase in the declared unit value is attributable to a manipulation of transfer prices by MNEs.

\footnotetext{
${ }^{51}$ In addition to the lack of significance, observe that the size of the coefficient is very low - the measure reduced discrepancies by only $9 \%$, column 8 -
} 
Table 8: Results, Unit value gap

\begin{tabular}{lllll}
\hline Variables & Unit value & Unit value & Unit value gap & Unit value gap \\
\hline & $(1)$ & $(2)$ & $(3)$ & $(4)$ \\
\hline Taxcredit & $\mathbf{- 0 . 0 3 9}$ & $\mathbf{- 0 . 0 4 6}$ & $\mathbf{0 . 0 3 2}$ & $\mathbf{0 . 0 3 8}$ \\
Cluster HS6 & $(0.205)$ & $(0.208)$ & $(0.108)$ & $(0.113)$ \\
Cluster HS4 & $(0.199)$ & $(0.203)$ & $(0.111)$ & $(0.123)$ \\
Cluster HS2 & $(0.170)$ & $(0.171)$ & $(0.073)$ & $(0.085)$ \\
PostResolution & $\mathbf{- 0 . 0 4 5}$ & $\mathbf{- 0 . 0 4 8}$ & $\mathbf{0 . 0 6 9}$ & $\mathbf{0 . 0 7 2}$ \\
Cluster HS6 & $(0.084)$ & $(0.084)$ & $(0.092)$ & $(0.092)$ \\
Cluster HS4 & $(0.080)$ & $(0.078)$ & $(0.091)$ & $(0.088)$ \\
Cluster HS2 & $(0.092)$ & $(0.090)$ & $(0.110)$ & $(0.107)$ \\
TaxcreditxPostResolution & $\mathbf{0 . 2 1 9}$ & $\mathbf{0 . 2 1 7}$ & $\mathbf{- 0 . 0 9 1}$ & $\mathbf{- 0 . 0 8 8}$ \\
Cluster HS6 & $(0.126)^{*}$ & $(0.124)^{*}$ & $(0.162)$ & $(0.163)$ \\
Cluster HS4 & $(0.124)^{*}$ & $(0.124)^{*}$ & $(0.164)$ & $(0.162)$ \\
Cluster HS2 & $(0.094)^{* *}$ & $(0.118)^{*}$ & $(0.127)$ & $(0.129)$ \\
Constant & $\mathbf{2 . 6 4 3}$ & $\mathbf{2 . 5 4 3}$ & $\mathbf{- 0 . 0 1 0}$ & $\mathbf{0 . 0 9 0}$ \\
Cluster HS6 & $(0.131)^{* * *}$ & $(0.134)^{* * *}$ & $(0.074)$ & $(0.078)$ \\
Cluster HS4 & $(0.143)^{* * *}$ & $(0.145)^{* * *}$ & $(0.074)$ & $(0.078)$ \\
Cluster HS2 & $(0.310)^{* * *}$ & $(0.321)^{* * *}$ & $(0.052)$ & $(0.060)$ \\
\hline Incoterm & CIF & FOB & CIF & FOB \\
Observations & 642 & 642 & 642 & 642 \\
R-squared & 0.002 & 0.002 & 0.001 & 0.001 \\
\hline
\end{tabular}

Notes:

(i) Observations are at the HS-6 product-trade partner-year level.

(ii) For a full definition of dependent variables, please see the text.

(iii) Coefficients are in bold, the row Cluster HS-6 presents standard errors clustered at the HS-6 digit level, the row Cluster HS-4 presents standard errors clustered at the HS-4 digit level, the row Cluster HS-2 presents standard errors clustered at the HS-2 digit level.

(iv) The coefficient is statistically significant from zero at the *** $1 \%,{ }^{* *} 5 \%,{ }^{*} 10 \%$ and $a 15 \%$ level.

(v) We use the ordinary least squares estimator. 


\section{Conclusion}

Since 2008, the Government of Ecuador has taxed capital leaving the country. Tax-credit measures on some imported goods - mainly intermediate goods - have been approved to promote local production. Results outline that these tax loopholes have been illegally exploited.

Following the introduction of the tax-credit measure, we observe an abnormal increase of the import value of eligible imports. To estimate the importer's response to the introduction of the tax deduction, we exploit the fact that multinationals have no incentives to modify their behaviors in setting transfer prices for products non eligible to the tax-credit measure. Then, relying on a differences-in-differences strategy, our estimates outline that, with the introduction of the tax-credit measure, the declared unit value of imports increased by $26 \%$. Various tests suggest that this increase is attributable to a profit-shifting behavior rather than a capital flight behavior.

Overall, this paper contributes to the profit-shifting literature by emphazing that customs authorities should play a substantial role in the fight against aggressive international tax planning. The study case notably stresses that customs should carefully monitor intragroup transactions. 


\section{References}

Aparicio, G., P. E. Carrillo, and M. Shahe Emran (2011): "Taxes, prisons, and CFOs: The effects of increased punishment on corporate tax compliance in Ecuador," Institute for International Economic Policy Working Paper.

Bartelsman, E. J., and R. M. Beetsma (2003): "Why pay more? Corporate tax avoidance through transfer pricing in OECD countries," Journal of Public Economics, $87(9), 2225-2252$.

Bauer, C. J., and D. Langenmayr (2013): "Sorting into outsourcing: Are profits taxed at a gorilla's arm's length?," Journal of International Economics, 90(2), 326-336.

Beer, S., And J. Loeprick (2014): "Profit shifting: Drivers of transfer (mis)pricing and the potential of countermeasures," International Tax and Public Finance, 22(3), 426-451.

Bernard, A. B., J. B. Jensen, and P. K. Schott (2006): "Transfer pricing by USbased multinational firms," NBER Working Paper.

Bertrand, M., E. Duflo, and S. Mullainathan (2004): "How much should we trust differences-in-differences estimates?," The Quarterly Journal of Economics, 119(1), 249275 .

Brada, J. C., A. M. Kutan, and G. Vukšić (2013): "Capital flight in the presence of domestic borrowing: Evidence from Eastern European economies," World development, $51,32-46$.

Buettner, T., G. Wamser, et Al. (2013): "Internal debt and multinational profit shifting: Empirical evidence from firm-level panel data," National Tax Journal, 66(1), 63-95.

Carrillo, P., D. Pomeranz, and M. Singhal (2016): "Dodging the taxman: Firm misreporting and limits to tax enforcement," American Economic Journal: Applied Economics (Forthcoming).

Carrillo, P. E., M. Shahe Emran, and R. Anita (2011): "Do cheaters bunch together? Profit taxes, withholding rates and tax evasion," Institute for International Economic Policy Working Paper.

Castellacci, F., and C. M. Lie (2015): "Do the effects of R\&D tax credits vary across industries? A meta-regression analysis," Research Policy, 44(4), 819-832.

Cevallos Pulley, E., and F. Garca Balda (2013): Double Taxation Agreements in Latin America. Analysis of the links among taxes, trade and responsible Financechap. Double taxation agreements in Ecuador, pp. 87-117. Latindadd.

Chalendard, C., G. Raballand, and A. Rakotoarisoa (2016): "The use of detailed statistical data in customs Reform. The case of Madagascar," World Bank Policy Research Working Paper. 
Clausing, K. A. (2003): "Tax-motivated transfer pricing and US intrafirm trade prices," Journal of Public Economics, 87(9), 2207-2223.

Cristea, A. D., And D. X. Nguyen (2016): "Transfer pricing by multinational firms: New evidence from foreign firm ownerships," AEJ: Economic Policy (Forthcoming).

Crivelli, E., R. A. De Mooij, and M. M. Keen (2015): "Base erosion, profit shifting and developing countries," IMF Working Papers.

Davies, R. B., J. Martin, M. Parenti, and F. Toubal (2015): "Knocking on tax haven's door: Multinational firms and transfer pricing," CEPR Working Papers.

De Mooij, R. A., And S. Ederveen (2008): "Corporate tax elasticities: A reader's guide to empirical findings," Oxford Review of Economic Policy, 24(4), 680-697.

Desai, M. A., C. F. Foley, and J. R. Hines (2004): "A multinational perspective on capital structure choice and internal capital markets," The Journal of Finance, 59(6), $2451-2487$.

(2006): "The demand for tax haven operations," Journal of Public economics, $90(3), 513-531$.

Devereux, M. P., And G. Maffini (2007): "The impact of taxation on the location of capital, firms and profit: A survey of empirical evidence," Oxford University Centre for Business Taxation Working Papers.

Dharmapala, D. (2014): "What do we know about base erosion and profit shifting? A review of the empirical literature," Fiscal Studies, 35(4), 421-448.

Díaz Tong, E., and K. Arenas Alvarado (2010): "Ecuador-new transfer pricing regulations," International Transfer Pricing Journal, 17(3), 219.

Dischinger, M., And N. Riedel (2011): "Corporate taxes and the location of intangible assets within multinational firms," Journal of Public Economics, 95(7), 691-707.

Egger, P., W. Eggert, C. KeuschnigG, And H. Winner (2010): "Corporate taxation, debt financing and foreign-plant ownership," European Economic Review, 54(1), 96-107.

Egger, P., And T. Seidel (2013): "Corporate taxes and intra-firm trade," European Economic Review, 63, 225-242.

Eurodad (2013): "Giving with one hand and taking with the other: Europe's role in taxrelated capital flight from developing countries," .

Feld, L. P., And J. H. Heckemeyer (2011): "FDI and taxation: A meta-study," Journal of Economic Surveys, 25(2), 233-272.

Feld, L. P., J. H. Heckemeyer, and M. Overesch (2013): "Capital structure choice and company taxation: A meta-study," Journal of Banking $\mathscr{E}$ Finance, 37(8), 2850-2866. 
Ferrantino, M. J., X. Liu, and Z. WAng (2012): "Evasion behaviors of exporters and importers: Evidence from the US-China trade data discrepancy," Journal of International Economics, 86(1), 141-157.

Fisman, R., And S.-J. Wei (2004): "Tax rates and tax evasion: Evidence from" missing imports" in China," Journal of Political Economy, 112(2).

Fuest, C., S. Hebous, and N. Riedel (2011): "International debt shifting and multinational firms in developing economies," Economics Letters, 113(2), 135-138.

Gravelle, J. G. (2009): "Tax havens: International tax avoidance and evasion," National Tax Journal, 62(4), 727-753.

Grubert, H. (2003): "Intangible income, intercompany transactions, income shifting, and the choice of location," National Tax Journal, 56(1), 221-242.

Grubert, H., And J. Mutti (1991): "Taxes, tariffs and transfer pricing in multinational corporate decision making," The Review of Economics and Statistics, 73(2), 285-293.

Gumpert, A., J. R. Hines JR, And M. Schnitzer (2016): "Multinational firms and tax havens," Review of Economics and Statistics (Forthcoming).

Heckemeyer, J., And M. Overesch (2013): "Multinationals' profit response to tax differentials: Effect size and shifting channels," ZEW-CEER Discussion Paper.

Hidalgo, D., M. Onofa, H. Oosterbeek, and J. Ponce (2013): "Can provision of free school uniforms harm attendance? Evidence from Ecuador," Journal of Development Economics, 103, 43-51.

Hiemann, M., And S. Reichelstein (2012): Fundamentals of International Transfer Pricing in Law and Economicschap. Transfer pricing in multinational corporations: An integrated management-and tax perspective, pp. 3-18. Springer.

Holguin, C. (2011): "Dramatic changes to the capital flight tax system in Ecuador," Discussion paper, Lataxnet.

Huizinga, H., L. Laeven, and G. Nicodeme (2008): "Capital structure and international debt shifting," Journal of Financial Economics, 88(1), 80-118.

Imbens, G. M., And J. M. WoOlDRIDGe (2009): "Recent developments in the econometrics of program evaluation," Journal of Economic Literature, 47(1), 5-86.

Kar, D., and D. Cartwright-Smith (2008): "Illicit financial flows from developing countries: 2002-2006," Discussion paper, Global Financial Integrity.

Karkinsky, T., And N. Riedel (2012): "Corporate taxation and the choice of patent location within multinational firms," Journal of International Economics, 88(1), 176-185.

Keen, M. (2013): Studies of Critical Issues in Taxation and Developmentchap. Taxation and development-Again. MIT Press. 
Keuschnigg, C., And M. P. Devereux (2013): "The arm's length principle and distortions to multinational firm organization," Journal of International Economics, 89(2), $432-440$.

LALL, S. (1973): "Transfer-pricing by multinational manufacturing firms," Oxford Bulletin of Economics and Statistics, 35(3), 173-195.

Lanz, R., and S. Miroudot (2011): "Intra-Firm Trade: patterns, determinants and policy implications," OECD Trade Policy Working Paper.

LATAXNET (2013): Managing corporate taxation in Latin American countries. An overview of main corporate taxes in selected jurisdictions 2015. Latin American Tax and Legal Network.

Lohse, T., P. Hofmann, and N. Riedel (2015): "Do transfer pricing laws limit international income shifting? Evidence from Europe," FZID Discussion Paper.

Mishra, P., A. Subramanian, and P. Topalova (2008): "Tariffs, enforcement, and customs evasion: Evidence from India," Journal of Public Economics, 92(10), 1907-1925.

Møen, J., D. Schindler, G. Schjelderup, and J. Tropina (2011): "International debt shifting: Do multinationals shift internal or external debt?," CESifo Working Papers.

Pastor, M. (1990): "Capital flight from latin America," World development, 18(1), 1-18.

Pomeranz, D. (2015): "Impact evaluation methods in public economics: A short introduction to randomized experiments and comparison with other methods," Public Finance Review (Forthcoming).

Ravallion, M. (2007): Handbook of Development Economicsvol. 4, chap. Evaluating antipoverty programs, pp. 3787-3846. Elsevier.

RIEdel, N. (2014): "Quantifying international tax avoidance: A review of the academic literature," ETPF Policy Paper.

Rijkers, B., L. Baghdadi, and G. Raballand (2015): "Political connections and tariff evasion evidence from Tunisia," The World Bank Economic Review (Forthcoming).

SAUnders-ScotT, M. (2013): "How does transfer-pricing enforcement affect reported profits?," .

UNCTAD (2015): "FDI, tax and development," UNCTAD Working Paper.

VICARD, V. (2015): "Profit shifting through transfer pricing: Evidence from French firm level trade data," Banque de France Document de Travail.

Weichenrieder, A. J. (2009): "Profit shifting in the EU: Evidence from Germany," International Tax and Public Finance, 16(3), 281-297. 


\section{A Appendix A: Supplementary tables}

Table 9: Summary statistics for the Unit value, by group

\begin{tabular}{lllllllllll}
\hline Group & Year & Mean & Median & Min & Max & SD & p5 & p25 & p75 & p95 \\
\hline Treatment & 2012 & 2.66 & 2.78 & -1.14 & 6.12 & 1.32 & 0.62 & 1.80 & 3.61 & 4.66 \\
& 2013 & 2.88 & 2.86 & -1.20 & 6.02 & 1.32 & 0.85 & 1.93 & 3.90 & 5.17 \\
\hline Control & 2012 & 2.62 & 2.42 & -1.39 & 7.19 & 1.53 & 0.43 & 1.50 & 3.69 & 5.54 \\
& 2013 & 2.58 & 2.40 & -1.19 & 6.48 & 1.50 & 0.49 & 1.50 & 3.69 & 5.29 \\
\hline
\end{tabular}

Notes:

(i) Observations are at the HS-10 product-trade partner-year level.

(ii) Unit value $_{p e t}=\ln (\text { Declared unit value })_{p e t}$, c.i.f.

(iii) SD is standard deviation, p stands for percentile in this table.

Table 10: Basic statistics, by section

\begin{tabular}{llll}
\hline Section & Section name & \# HS10 & \# HS10 \\
\hline & & Treatment group & Control group \\
\hline II & Vegetables & 1 & 1 \\
IV & Prepared foodstruffs, beverages, tobacco & 4 & 6 \\
V & Minerals & 3 & 5 \\
VI & Chemical and allied industries & 22 & 35 \\
VII & Plastics, rubber & 21 & 43 \\
X & Wood or other fibrous cellulosic materia & 13 & 23 \\
XII & Textile & 2 & 3 \\
XIII & Stone, ceramic, glass and glassware & 5 & 6 \\
XV & Base metals & 39 & 42 \\
XVI & Machinery, mechanical appliance & 40 & 29 \\
\hline
\end{tabular}

Notes:

(i) \# HS10 is the number of HS10-products.

(ii) A section is a cluster of HS2-chapters.

\section{B Appendix B: F101 form}




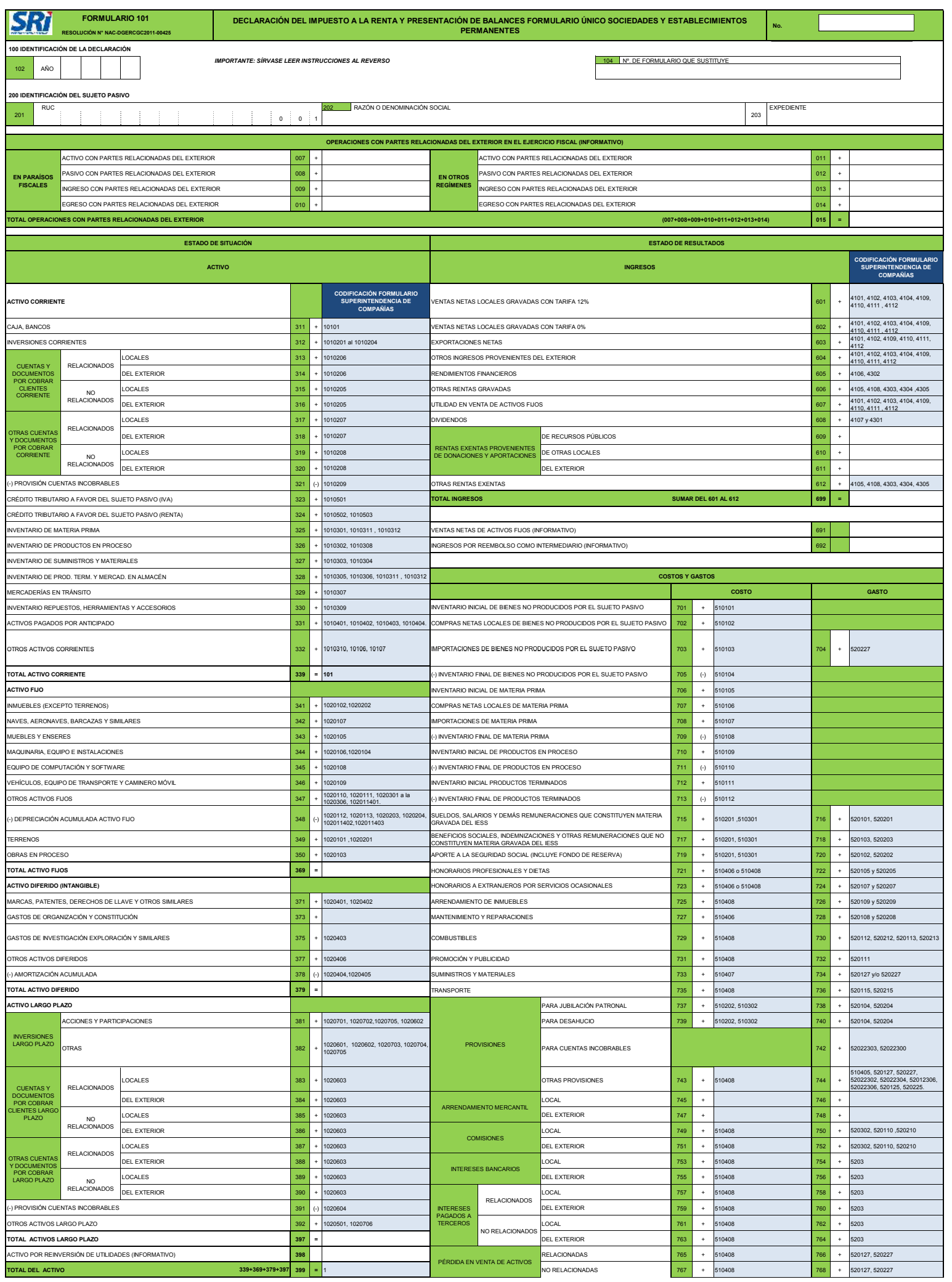




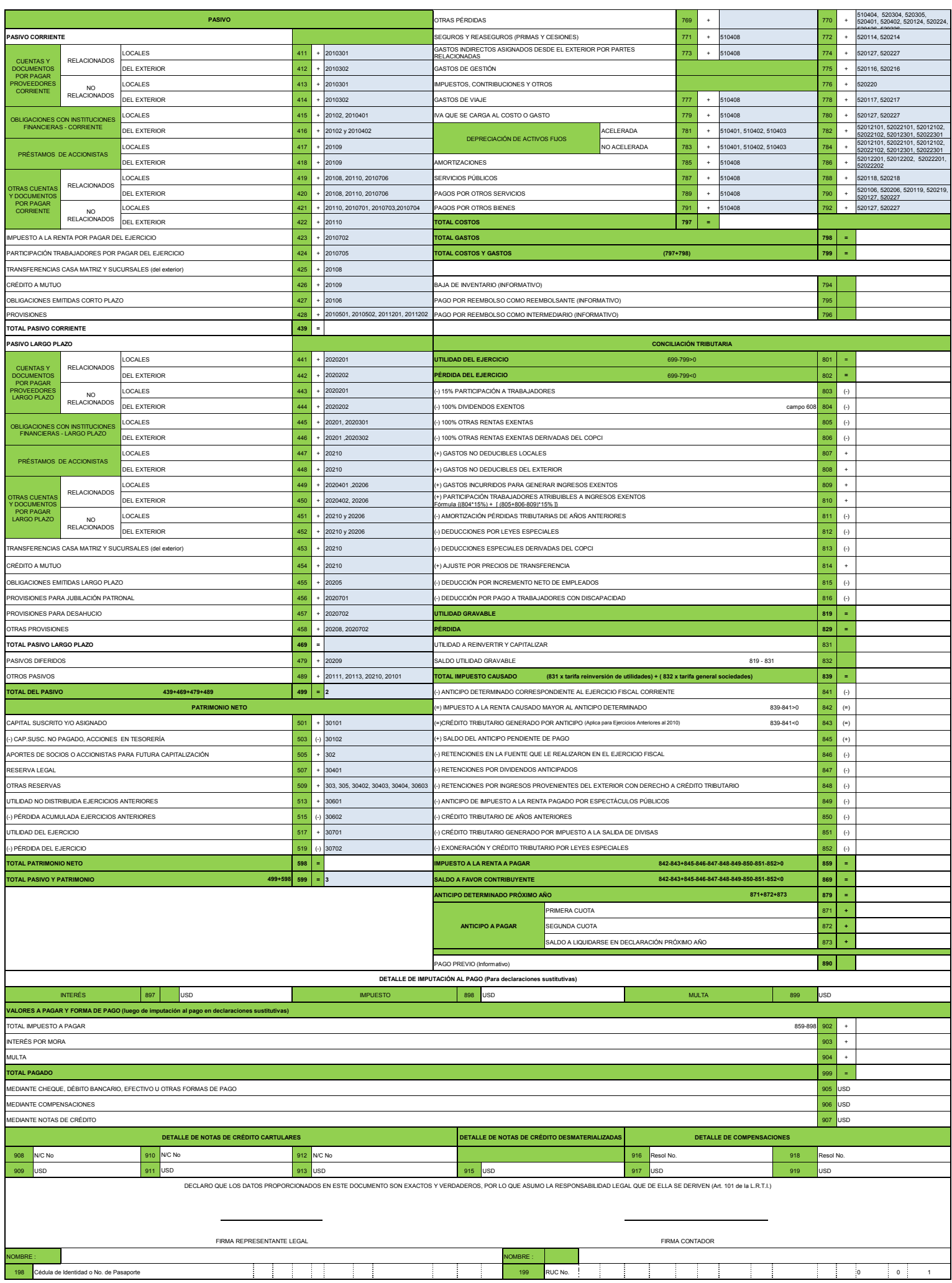


Table 11: Baseline results, use of an unbalanced sample

\begin{tabular}{lllllll}
\hline Variables & Unit value & Unit value & Unit value & Unit value & Unit value & Unit value \\
\hline & $(1)$ & $(2)$ & $(3)$ & $(4)$ & $(5)$ & $(6)$ \\
\hline Taxcredit & $\mathbf{- 0 . 1 9 1}$ & $\mathbf{- 0 . 1 6 3}$ & $\mathbf{- 0 . 2 5 5}$ & $\mathbf{- 0 . 1 9 0}$ & $\mathbf{- 0 . 1 6 2}$ & $\mathbf{- 0 . 2 5 3}$ \\
Cluster HS6 & $(0.124)$ & $(0.123)$ & $(0.133)^{*}$ & $(0.122)$ & $(0.121)$ & $(0.131)^{*}$ \\
Cluster HS4 & $(0.132)$ & $(0.131)$ & $(0.138)^{*}$ & $(0.130)$ & $(0.129)$ & $(0.135)^{*}$ \\
Cluster HS2 & $(0.133)$ & $(0.128)$ & $(0.156) \mathrm{a}$ & $(0.133)$ & $(0.128)$ & $(0.152)^{\mathrm{a}}$ \\
PostResolution & $\mathbf{- 0 . 0 4 9}$ & $\mathbf{- 0 . 0 1 1}$ & $\mathbf{- 0 . 0 2 9}$ & $\mathbf{- 0 . 0 4 8}$ & $\mathbf{- 0 . 0 1 0}$ & $\mathbf{- 0 . 0 2 7}$ \\
Cluster HS6 & $(0.093)$ & $(0.093)$ & $(0.105)$ & $(0.093)$ & $(0.093)$ & $(0.105)$ \\
Cluster HS4 & $(0.082)$ & $(0.085)$ & $(0.090)$ & $(0.082)$ & $(0.085)$ & $(0.090)$ \\
Cluster HS2 & $(0.093)$ & $(0.096)$ & $(0.110)$ & $(0.093)$ & $(0.097)$ & $(0.111)$ \\
TaxcreditxPostResolution & $\mathbf{0 . 2 6 6}$ & $\mathbf{0 . 2 0 9}$ & $\mathbf{0 . 2 6 8}$ & $\mathbf{0 . 2 6 0}$ & $\mathbf{0 . 2 0 3}$ & $\mathbf{0 . 2 6 7}$ \\
Cluster HS6 & $(0.133)^{* *}$ & $(0.129)^{*} \mathrm{a}$ & $(0.151)^{*}$ & $(0.133)^{*}$ & $(0.129)^{\mathrm{a}}$ & $(0.151)^{*}$ \\
Cluster HS4 & $(0.130)^{* *}$ & $(0.126)^{*}$ & $(0.148)^{*}$ & $(0.130)^{* *}$ & $(0.125)^{*}$ & $(0.147)^{*}$ \\
Cluster HS2 & $(0.103)^{* *}$ & $(0.096)^{* *}$ & $(0.132)^{*}$ & $(0.106)^{* *}$ & $(0.098)^{*}$ & $(0.133)^{*}$ \\
Constant & $\mathbf{1 . 2 2 0}$ & $\mathbf{1 . 1 0 2}$ & $\mathbf{1 . 4 2 0}$ & $\mathbf{1 . 5 5 6}$ & $\mathbf{1 . 4 3 7}$ & $\mathbf{1 . 4 2 3}$ \\
Cluster HS6 & $(0.705)^{*}$ & $(0.719)$ & $(0.730)^{*}$ & $(0.813)^{*}$ & $(0.826)^{*}$ & $(0.796)^{*}$ \\
Cluster HS4 & $(0.708)^{*}$ & $(0.723)$ & $(0.734)^{*}$ & $(0.822)^{*}$ & $(0.835)^{*}$ & $(0.837)^{*}$ \\
Cluster HS2 & $(0.108)^{* * *}$ & $(0.119)^{* * *}$ & $(0.125)^{* * *}$ & $(0.343)^{* * *}$ & $(0.336)^{* * *}$ & $(0.547)^{* *}$ \\
\hline Incoterm & CIF & FOB & CIF & CIF & FOB & CIF \\
Sample & DTA & DTA & No neighbours & DTA & DTA & No neighbours \\
Tax variables & No & No & No & Yes & Yes & Yes \\
Observations & 754 & 754 & 617 & 754 & 754 & 617 \\
R-squared & 0.433 & 0.431 & 0.420 & 0.435 & 0.433 & 0.420 \\
\hline
\end{tabular}

Notes:

(i) Observations are at the HS-10 product-trade partner-year level.

(ii) The dependent variable is the Unit value $=\ln ($ Declared unit value). The incoterm is cost insurance and freight (CIF) or free on board (FOB).

(iii) All regressions include fixed effects for HS2-industries and trade partners.

(iv) The sample 'DTA' is formed by imports (i) with an import taxation rate (excluding VAT) lesser than the corporate income tax differential (ii) coming from 20 top source countries of foreign direct investment into Ecuador and (iii) originating from a country having signed a double taxation agreement with Ecuador ; imports from tax havens or very low-tax jurisdictions are excluded. The sample 'No neighbours' is formed by imports (i) with an import taxation rate (excluding the VAT) lesser than the corporate income tax differential (ii) coming from 20 top source countries of foreign direct investment into Ecuador and (iii) originating from a country having signed a double taxation agreement with Ecuador ; imports from neighbours countries, tax havens or very low-tax jurisdictions are excluded.

(v) Coefficients are in bold, the row Cluster HS-6 presents standard errors clustered at the HS-6 digit level, the row Cluster HS-4 presents standard errors clustered at the HS-4 digit level, the row Cluster HS-2 presents standard errors clustered at the HS-2 digit level.

(vi) The coefficient is statistically significant from zero at the *** $1 \%,{ }^{* *} 5 \%, * 10 \%$ and $a 15 \%$ level.

(vii) We use the ordinary least squares estimator. 
Table 12: Number of observations, by trading partner

\begin{tabular}{|c|c|c|c|c|c|c|c|}
\hline Country & Code & Tax haven & Top FDI & DTA & \# HS10 & \# HS10 & \# HS10 \\
\hline Group & & & & & Treatment & Control & All \\
\hline Austria & $\mathrm{AT}$ & & & & 4 & 2 & 6 \\
\hline Belgium & $\mathrm{BE}$ & & & Yes & 1 & 1 & 2 \\
\hline Canada & $\mathrm{CA}$ & & Yes & Yes & 1 & 1 & 2 \\
\hline Chile & CL & & Yes & Yes & 33 & 57 & 90 \\
\hline China & $\mathrm{CN}$ & & Yes & & 18 & 27 & 45 \\
\hline Colombia & $\mathrm{CO}$ & & Yes & Yes & 3 & 3 & 6 \\
\hline Costa Rica & $\mathrm{CZ}$ & & & & 6 & 5 & 11 \\
\hline Denmark & DK & & & & 4 & 1 & 5 \\
\hline Finland & FI & & Yes & & 1 & 2 & 3 \\
\hline Germany & $\mathrm{DE}$ & & Yes & Yes & 84 & 100 & 184 \\
\hline Hong-Kong & HK & Yes & & & 24 & 17 & 41 \\
\hline Hungary & $\mathrm{HU}$ & & & & 1 & 1 & 2 \\
\hline India & IN & & & & 1 & 2 & 3 \\
\hline Indonesia & ID & & & & 2 & 2 & 4 \\
\hline Ireland & IE & Yes & & & 8 & 4 & 12 \\
\hline Israel & IL & & & & 2 & 1 & 3 \\
\hline Italy & IT & & Yes & Yes & 13 & 9 & 22 \\
\hline Japan & JP & & & & 8 & 6 & 14 \\
\hline Korea, Rep & $\mathrm{KR}$ & & & & 23 & 26 & 49 \\
\hline Latvia & LV & & & & 1 & 3 & 4 \\
\hline Malaysia & MY & & & & 4 & 6 & 10 \\
\hline Mexico & MX & & Yes & Yes & 2 & 2 & 4 \\
\hline Netherlands & NL & & Yes & & 17 & 22 & 39 \\
\hline Panama & PA & Yes & Yes & & 2 & 4 & 6 \\
\hline Peru & $\mathrm{PE}$ & & Yes & Yes & 12 & 20 & 32 \\
\hline Poland & PL & & & & 7 & 9 & 16 \\
\hline Romania & $\mathrm{RO}$ & & & Yes & 10 & 3 & 13 \\
\hline Singapore & $\mathrm{SG}$ & & & & 29 & 15 & 44 \\
\hline Slovakia & SK & & & & 1 & 1 & 2 \\
\hline Slovenia & SI & & & & 2 & 1 & 3 \\
\hline Spain & $\mathrm{ES}$ & & Yes & Yes & 2 & 1 & 3 \\
\hline Sweden & $\mathrm{SE}$ & & & & 8 & 5 & 13 \\
\hline Switzerland & $\mathrm{CH}$ & Yes & Yes & Yes & 45 & 40 & 85 \\
\hline Taiwan & TW & & & & 45 & 61 & 106 \\
\hline Thailand & $\mathrm{TH}$ & & & & 6 & 7 & 13 \\
\hline Turkey & $\mathrm{TR}$ & & & & 1 & 4 & 5 \\
\hline Ukraine & UA & & & & 3 & 1 & 4 \\
\hline United Arab Emirates & $\mathrm{AE}$ & Yes & & & 3 & 1 & 4 \\
\hline United Kingdom & GB & & Yes & & 9 & 11 & 20 \\
\hline Uruguay & UY & & & Yes & 2 & 3 & 5 \\
\hline VietNam & $\mathrm{VN}$ & & & & 2 & 3 & 5 \\
\hline
\end{tabular}

Notes:

(i) \# HS10 is the number of HS10-products.

(ii) 'Tax haven' indicates that the country is a tax haven or a very low-tax jurisdiction.

(iii) 'Top FDI' indicates that the country belongs to the 20 top source countries of foreign direct investment into Ecuador.

(iv) 'DTA' indicates that the country has signed a double taxation agreement with Ecuador. 
Table 13: Different sample restrictions

\begin{tabular}{lllll}
\hline Variables & Unit value & Unit value & Unit value & Unit value \\
\hline Taxcredit & $(1)$ & $(2)$ & $(3)$ & $(4)$ \\
Cluster HS6 & $\mathbf{- 0 . 0 3 7}$ & $\mathbf{- 0 . 0 1 9}$ & $\mathbf{- 0 . 0 4 5}$ & $\mathbf{0 . 0 3 9}$ \\
Cluster HS4 & $(0.263)$ & $(0.280)$ & $(0.218)$ & $(0.191)$ \\
Cluster HS2 & $(0.264)$ & $(0.284)$ & $(0.219)$ & $(0.189)$ \\
PostResolution & $(0.222)$ & $(0.242)$ & $(0.199)$ & $(0.158)$ \\
Cluster HS6 & $\mathbf{- 0 . 0 6 7}$ & $\mathbf{- 0 . 0 4 8}$ & $\mathbf{- 0 . 0 0 4}$ & $\mathbf{- 0 . 0 4 7}$ \\
Cluster HS4 & $(0.055)$ & $(0.058)$ & $(0.080)$ & $(0.093)$ \\
Cluster HS2 & $(0.054)$ & $(0.052)$ & $(0.072)$ & $(0.083)$ \\
TaxcreditxPostResolution & $(0.059)$ & $(0.047)$ & $(0.072)$ & $(0.098)$ \\
Cluster HS6 & $\mathbf{0 . 1 3 7}$ & $\mathbf{0 . 1 4 5}$ & $\mathbf{0 . 1 9 2}$ & $\mathbf{0 . 2 6 4}$ \\
Cluster HS4 & $(0.090) \mathrm{a}$ & $(0.094) \mathrm{a}$ & $(0.115)^{*}$ & $(0.134)^{*}$ \\
Cluster HS2 & $(0.084) \mathrm{a}$ & $(0.093) \mathrm{a}$ & $(0.112)^{*}$ & $(0.133)^{* *}$ \\
Constant & $(0.122)$ & $(0.112)$ & $(0.109)^{*}$ & $(0.109)^{* *}$ \\
Cluster HS6 & $\mathbf{2 . 9 8 0}$ & $\mathbf{2 . 8 5 9}$ & $\mathbf{2 . 7 0 6}$ & $\mathbf{2 . 6 2 4}$ \\
Cluster HS4 & $(0.242)^{* * *}$ & $(0.252)^{* * *}$ & $(0.181)^{* * *}$ & $(0.146)^{* * *}$ \\
Cluster HS2 & $(0.244)^{* * *}$ & $(0.255)^{* * *}$ & $(0.189)^{* * *}$ & $(0.160)^{* * *}$ \\
\hline Sample & $(0.324)^{* * *}$ & $(0.349)^{* * *}$ & $(0.288)^{* * *}$ & $(0.262)^{* * *}$ \\
Observations & $\psi<\Delta$ CIT & No tax haven & FDI & DTA \\
R-squared & 1,880 & 1,584 & 900 & 686 \\
\hline
\end{tabular}

Notes:

(i) Observations are at the HS-10 product-trade partner-year level.

(ii) The dependent variable is the Unit value $=\ln ($ Declared unit value). The incoterm is cost insurance and freight (CIF) or free on board (FOB).

(iii) The sample ' $\psi<\Delta$ CIT' is formed by imports with an import taxation rate (excluding VAT) lesser than the corporate income tax differential. The sample 'No tax haven' is formed by imports (i) with an import taxation rate (excluding the VAT) lesser than the corporate income tax differential and (ii) not coming from a tax haven or a very low-tax jurisdiction. The sample 'FDI' is formed by imports (i) with an import taxation rate (excluding the VAT) lesser than the corporate income tax differential and (ii) coming from 20 top source countries of foreign direct investment into Ecuador; we continue to exclude imports from tax havens or very low-tax jurisdictions. The sample 'DTA' is formed by imports (i) with an import taxation rate (excluding the VAT) lesser than the corporate income tax differential (ii) coming from 20 top source countries of foreign direct investment into Ecuador and (iii) originating from a country having signed a double taxation agreement with Ecuador; we continue to exclude imports from tax havens or very low-tax jurisdictions.

(iv) Coefficients are in bold, the row Cluster HS-6 presents standard errors clustered at the HS-6 digit level, the row Cluster HS-4 presents standard errors clustered at the HS-4 digit level, the row Cluster HS-2 presents standard errors clustered at the HS-2 digit level.

(v) The coefficient is statistically significant from zero at the ${ }^{* * *} 1 \%,{ }^{* *} 5 \%,{ }^{*} 10 \%$ and $a 15 \%$ level.

(vi) We use the ordinary least squares estimator. 
Table 14: Case $\psi>\Delta$ CIT

\begin{tabular}{lllll}
\hline Variables & Unit value & Unit value & Unit value & Unit value \\
\hline Taxcredit & $(1)$ & $(2)$ & $(3)$ & $(4)$ \\
Cluster HS6 & $\mathbf{0 . 3 0 1}$ & $\mathbf{0 . 3 0 0}$ & $\mathbf{0 . 2 7 6}$ & $\mathbf{0 . 1 1 1}$ \\
Cluster HS4 & $(0.112)^{* * *}$ & $(0.113)^{* * *}$ & $(0.105)^{* * *}$ & $(0.123)$ \\
Cluster HS2 & $(0.127)^{* *}$ & $(0.126)^{* *}$ & $(0.109)^{* *}$ & $(0.126)$ \\
PostResolution & $(0.095)^{* * *}$ & $(0.096)^{* * *}$ & $(0.133)^{* *}$ & $(0.139)$ \\
Cluster HS6 & $\mathbf{0 . 0 6 6}$ & $\mathbf{0 . 0 7 3}$ & $\mathbf{0 . 0 7 6}$ & $\mathbf{0 . 1 5 3}$ \\
Cluster HS4 & $(0.036)^{*}$ & $(0.036)^{* *}$ & $(0.046)^{*}$ & $(0.058)^{* * *}$ \\
Cluster HS2 & $(0.042) \mathrm{a}$ & $(0.043)^{*}$ & $(0.048) \mathrm{a}$ & $(0.058)^{* * *}$ \\
TaxcreditxPostResolution & $(0.027)^{* *}$ & $(0.027)^{* *}$ & $(0.034)^{* *}$ & $(0.043)^{* * *}$ \\
Cluster HS6 & $(0.063)$ & $(0.064)$ & $\mathbf{- 0 . 0 1 1}$ & $\mathbf{- 0 . 0 4 6}$ \\
Cluster HS4 & $(0.066)$ & $(0.065)$ & $(0.079)$ & $(0.115)$ \\
Cluster HS2 & $(0.053)$ & $(0.050)$ & $(0.084)$ & $(0.122)$ \\
Constant & $\mathbf{2 . 5 8 7}$ & $\mathbf{2 . 5 8 6}$ & $(0.068)$ & $(0.115)$ \\
Cluster HS6 & $(0.067)^{* * *}$ & $(0.068)^{* * *}$ & $(0.060)^{* * *}$ & $(0.068)^{* * *}$ \\
Cluster HS4 & $(0.083)^{* * *}$ & $(0.083)^{* * *}$ & $(0.072)^{* * *}$ & $(0.076)^{* * *}$ \\
Cluster HS2 & $(0.171)^{* * *}$ & $(0.171)^{* * *}$ & $(0.145)^{* * *}$ & $(0.140)^{* * *}$ \\
\hline Sample & $\psi>\Delta \mathrm{CIT}$ & No tax haven & FDI & DTA \\
Observations & 4,726 & 4,642 & 2,886 & 1,664 \\
R-squared & 0.009 & 0.009 & 0.009 & 0.004 \\
\hline
\end{tabular}

Notes:

(i) Observations are at the HS-10 product-trade partner-year level.

(ii) The dependent variable is the Unit value $=\ln ($ Declared unit value). The incoterm is cost insurance and freight (CIF) or free on board (FOB).

(iii) The sample ' $\psi>\Delta$ CIT' is formed by imports with an import taxation rate (excluding VAT) greater than the corporate income tax differential. The sample 'No tax haven' is formed by imports (i) with an import taxation rate (excluding the VAT) greater than the corporate income tax differential and (ii) not coming from a tax haven or a very low-tax jurisdiction. The sample 'FDI' is formed by imports (i) with an import taxation rate (excluding the VAT) greater than the corporate income tax differential and (ii) coming from 20 top source countries of foreign direct investment into Ecuador ; we continue to exclude imports from tax havens or very low-tax jurisdictions. The sample 'DTA' is formed by imports (i) with an import taxation rate (excluding the VAT) greater than the corporate income tax differential (ii) coming from 20 top source countries of foreign direct investment into Ecuador and (iii) originating from a country having signed a double taxation agreement with Ecuador ; we continue to exclude imports from tax havens or very low-tax jurisdictions.

(iv) Coefficients are in bold, the row Cluster HS-6 presents standard errors clustered at the HS-6 digit level, the row Cluster HS-4 presents standard errors clustered at the HS-4 digit level, the row Cluster HS-2 presents standard errors clustered at the HS-2 digit level.

(v) The coefficient is statistically significant from zero at the ${ }^{* * *} 1 \%,{ }^{* *} 5 \%,{ }^{*} 10 \%$ and $a 15 \%$ level.

(vi) We use the ordinary least squares estimator. 